\title{
PRAWO PRZYRODZONE W EMPIRYCZNYM UJĘCIU
}

Od wielu wieków różni myśliciele rozważają, czy istnieje jakaś przedmiotowa podstawa, różna od prawodawstwa państwowego, uznawania pewnych rodzajów postępowania oraz ustaw za dobre, godziwe, sprawiedliwe, względnie przeciwnie: za złe, naganne, niegodziwe; innymi słowy: czy wartość czynów ludzkich, a wśród nich także ustaw, opiera się na jakiejś przedmiotowej rzeczywistości, która by mogła być sprawdzianem godziwości postępowania ludzkiego oraz praw, niezależnie od nastawienia uczuciowego jednostek czy grup społecznych, uwarunkowanego przez stosunki polityczne i gospodarcze, rozwój kultury oraz odziedziczone nawyki myślenia.

Jeszcze w r. 1935 wybitny filozof angielski B. Russell mógł napisać: „Jeśli dwie osoby różnią się $\mathrm{w}$ ocenach, spór ich nie dotyczy zagadnienia prawdziwości lecz polega na różnicy smaków [...] nie potrafimy bowiem znaleźć argumentów, które dowodziłyby, że to lub tamto ma wartość bezwzględną. Nie możemy udowodnić daltoniście, że trawa jest zielona, a nie czerwona. [...] Skoro nie można nawet wyobrazić sobie, jakby tu rozstrzygnąć jakąś różnicę opinii w sprawie wartości, zmuszeni jesteśmy do wniosku, że różnica ta jest różnicą co do gustu, nie zaś co do jakiejś prawdy obiektywnej" ${ }^{1}$. Ale w 20 lat później tenże myśliciel stwierdził, że wobec okrucieństw, popełnianych przez zbrodniarzy wojennych, którzy zgodnie z ideologią, a nawet ustawodawstwem Niemiec hitlerowskich, wymordowali miliony niewinnych osób, w tym ponad dwa miliony dzieci, trudno zajmować postawę: de gustibus non est disputandum" ${ }^{2}$. Proces norymberski przeciw tym zbrodniarzom był wyrazem powszechnego przeświadczenia, że moralność nie jest sprawą samego tylko gustu lub ustawodawstwa, lecz winna być urzeczywistnieniem jakiegoś wyższego prawa, które by mogło być podstawą i miarą godziwości tak czynów poszczególnych ludzi, jak i narodów oraz ustaw stanowiąc równocześnie sprawdzian obowiązywania lub nieobowiązywania wszelkich innych praw czy obyczajów.

1 B. Russell, Religion and Science, London 1934, 244.

2 B. Russell, Human Society in Ethics and Politics, London 1954, 89.

10 - Analecta Cracoviensia 
Już ponad dwa tysiące lat temu Arystoteles i Cyceron nazwali to wyższe prawo prawem ludzkiej natury. Teorię tegoż prawa opracował w XIII w. św. Tomasz z Akwinu, w XV w. zaś rozwinął ją i zastosował do życia międzynarodowego nasz rodak Paweł Włodkowic z Brudzewa, a nieco później i wszechstronniej Franciszek de Vittoria i Hugo Grotius. Deklaracja Stanów Zjednoczonych, przyjmując prawo naturalne za swą podstawę, głosi: „Za oczywiste uważamy te prawdy: że wszyscy ludzie są stworzeni jako równi sobie, że wszyscy zostali wyposażeni przez Stwórcę $\mathrm{w}$ pewne niezbywalne prawa, do których zalicza się prawo do życia, prawo do wolności oraz prawo dążenia do szczęścia" ${ }^{3}$. Ale już Ernst Troeltsch w r. 1934 pisał, że w Niemczech pojęcia: „prawo naturalne” i „natura ludzka” stały się zupełnie niezrozumiałe i straciły swoją pierwotną wyrazistość", z jakim skutkiem - pokazała druga wojna światowa ${ }^{4}$. Dziś nie tylko w Niemczech, ale nawet w Ameryce, chociaż jeszcze mówi się o niesprawiedliwych prawach i wyrokach sądowych w niektórych krajach, wielu odrzuca istnienie normy słuszności, niezależnej od ustaw państwowych, a jeśli nawet przyjmuje się ją, to chyba w znaczeniu ideału, różnie pojmowanego w różnych cywilizacjach. A przecież stawia się nieraz pod znak zapytania, czy ideały danego społeczeństwa są słuszne i bada się, które spośród nich uznać za podstawowe, a które za wtórne, by postępowanie ludzkie nie było owocem ślepego wyboru lub wypadkową gry naszych popędów, przesądów czy odziedziczonych nawyków. Za taką podstawę uchodziło prawo naturalne.

Zagadnieniu prawa naturalnego poświęcono tysiące rozpraw, ujmujących je zazwyczaj z metafizycznego lub historycznego punktu widzenia. Ale słusznie zauważył ks. W. Piwowarski, że ,zasadniczym błędem $\mathrm{w}$ badaniach nad prawem naturalnym było rozpatrywanie go wyłącznie na płaszczyźnie filozoficznej, podczas gdy stanowi ono domenę nauk szczegółowych, a zwłaszcza socjologii" ${ }^{5}$.

Ponieważ wyrażenie ,prawo naturalne” jest bardzo wieloznaczne i ściśle związane z metafizycznym i teologicznym ujęciem natury ludzkiej, wolimy za o. J. Woronieckim ${ }^{6}$, posługiwać się wyrazem mniej wieloznacznym „,przyrodzone”, wyraz zaś „naturalny” zachować w przedstawianiu poglądów innych autorów. Jak zaznaczymy niebawem, to „prawo przyrodzone" zakresowo utożsamia się z ,prawem naturalnym” w dynamicznym ujęciu św. Tomasza, ale różni się od niego treściowo, gdyż nie uwzględnia jego teologicznej i metafizycznej treści. Nie będzie to pełne ujęcie tegoż prawa ale tylko szkicowe i ramowe w nadziei, że z czasem

3 Cyt. za L. Strauss, Prawo naturalne w świetle historii, Warszawa 1969, 9.

4 Tamże.

5 Ks. Wł. Piwowarski, Socjologia moralności a ,prawo naturalne”, w: Roczniki Filozoficzne, 18 (1970), z. 2, 94.

- O. J. Woroniecki, Katolicka etyka wychowawcza, Kraków 1948, 204. 
fachowcy $w$ takich naukach empirycznych jak antropologia, psychologia i socjologia wypełnią kiedyś te ramy bogatym tworzywem, które będzie mogło stać się podstawą do coraz dokładniejszego sformułowania ocen i norm postępowania moralnego, stanowiących treść prawa przyrodzonego.

\section{POJECIE PRAWA PRZYRODZONEGO I JEGO POZNAWALNOSĆ}

Dobrym zwyczajem w każdej nauce jest zaczynanie wykładu od określenia jej przedmiotu albo przynajmniej od porozumienia się ze słuchaczami względnie czytelnikami, w jakim znaczeniu będzie się używało podstawowych w tej nauce wyrazów, gdyż inaczej o każdym przedmiocie możnaby wypowiadać sądy sprzeczne i toczyć nigdy nie kończące się spory. Jak wiadomo, można definiować zarówno rzeczy istniejące $\mathrm{w}$ rzeczywistym świecie jak też i byty myślne, których urzeczywistnienie jest albo niemożliwe, albo jest możliwe tylko $\mathrm{w}$ przybliżeniu, $\mathrm{np}$. gdy określamy kwadrat jako prostokąt równoboczny, choć w świecie rzeczywistym nie ma ani kwadratów ani prostokątów równobocznych. Wystarczy popatrzeć przez mikroskop na jak najlepiej narysowany kwadrat, by się o tym przekonać. Rzeczy istniejące $\mathrm{w}$ świecie rzeczywistym $\mathrm{w}$ przeszłości, obecnie lub przyszłości możemy określać już to rzeczowo, czyli w języku przedmiotowym, już to nominalnie w języku metateorii, odnoszącym się nie do przedmiotów nauki ale do wyrazów, w których ta nauka jest przedstawiona. Jedne i drugie definicje mogą być już to sprawozdawcże, np. takie które odpowiadają na pytanie, co znaczy dany wyraz $\mathrm{W}$ jakimś zastanym sposobie mówienia, albo projektujące "gdy wprowadzają do języka nowe wyrażenie, ustalając jego znaczenie jako pewne zestawienie znaczeń wyrazów już należących do danego języka" ? W tym drugim znaczeniu usiłujemy tu określić „,prawo przyrodzone" w odróżnieniu od praw przyrodniczych i od praw naturalnych w metafizycznym ujęciu, podczas gdy my będziemy się starali podać empiryczne ujęcie prawa przyrodzonego.

Przez „ujęcie empiryczne" rozumiemy tu przedstawienie pewnego przedmiotu przy pomocy zdań spostrzeżeniowych, czyli wypowiadających jakiś sąd na podstawie sprawdzonych lub sprawdzalnych spostrzeżeń, dokonanych przy pomocy zmysłów. Przez zdania „empiryczne” rozumiemy więc wypowiedzi, które wyrażają rzeczywistość spostrzeganą bezpośrednio lub pośrednio przy pomocy zmysłów. Należy jednak pamiętać o przestrodze K. Ajdukiewicza, że „każda nauka [...] zawierać musi poznanie aprioryczne i że nawet $\mathrm{w}$ poznaniu empirycznym zawierają się elementy

7 T. Czeżowski, Definicje analityczne i syntetyczne, w: Studia Filozoficzne, 47 (1966), z. 4, 5 . 
wyznaczone przez język niezależnie od doświadczenia" ". Przyjmując to zastrzeżenie, nie widzimy potrzèby poszerzenia pojęcia „doświadczenie" jako „bezpośredniego i kontrolowanego kontaktu z rzeczywistością" ".

By określić prawo przyrodzone $\mathrm{w}$ odróżnieniu od praw przyrodniczych i praw naturalnych w ujęciu metafizycznym, nie można pominąć milczeniem definicji tychże praw. Ponieważ jednak istnieją tysiące takich definicji, musimy się ograniczyć do tych, które wydają się nam bardziej typowe. Np. prawo przyrodnicze jedni określają jako z zewnątrz narzucony rzeczom stały ich sposób działania, inni jako uogólnienie spostrzeżeń w postaci funkcji wyrażonych na wzór funkcji matematycznych, lub jako przyczynowe albo formalne związki między wielkościami fizycznymi lub własnościami, jeszcze inni jako prawidłowości zachodzące w dostatecznie wielkim zbiorowisku zjawisk, lub jako schematy zjawisk, będące przybliżonym uproszczeniem rzeczywistości, jako reguły postępowania dla badaczy, nie dające się sprawdzić empirycznie odnośnie do wszystkich przypadków; wreszcie konwencjonaliści, tacy jak H. Poincaré, P. Duhem i K. Ajdukiewicz uznają prawa przyrodnicze za dowolne umowy, postulaty lub definicje, ustalające znaczenie podstawowych pojęć, a nie za jakąś rzeczywistość, bo zakładają ich pełną sprawdzalność $\mathrm{w}$ idealnych warunkach, niemożliwych do urzeczywistnienia, np. w bezwzględnej próżni, w systemie całkowicie odizolowanym itp. ${ }^{10}$

Jeszcze większa rozbieżność zdań zachodzi w próbach zdefiniowania prawa naturalnego. Tak np. św. Tomasz z Akwinu określa je jako „uczestnictwo odwiecznego prawa Bożego w rozumnej naturze człowieka", ujmując je ,jako ukierunkowanie postępowania ludzkiego do celu ostatecznego, ujawniające się w skłonnościach natury ludzkiej" ${ }^{11}$. Tomista A. F. Utz ujmuje prawo naturalne jako ,powinność uświadomioną w stosunku naturalnym $\mathrm{w}$ sumieniu ludzkim, które domaga się osiągania wartości społecznych" 12. B. Häring powiada, że „W etyce prawo naturalne oznacza samą naturę człowieka w jego konkretnej historycznej rzeczywistości, w tym stopniu, w jakim zdolny on jest zrozumieć siebie, swe wezwanie czy powołanie oraz znaczenie swej osoby i jej stosunku do Boga, bliźnich i do stworzonego świata" ${ }^{13}$. Cz. Strzeszewski prawem naturalnym nazywa ,,prawo rządzące światem, będące odbiciem odwiecz-

8 K. Ajdukiewicz, Zagadnienie empiryzmu a koncepcja znaczenia, w: Studia Filozoficzne, 38 (1964), z. 1, 10.

${ }^{9} \mathrm{Ks}$. T. Styczeń, O niektórych próbach rozwiązania problemu etyki, w: Roczniki Filozoficzne, 19 (1971), z. 9.

$10 \mathrm{Ks}$. Stanisław Mazierski, Koncepcje praw przyrody, w: Zeszyty Naukowe KUL, 10 (1967), z. 2, 25-36.

11 Sw. Tomasz z Akwinu, Summa theologica, I-II, q. 91, a. 2.

12 A. F. Utz, Probleme des Naturrechts in der positiven Rechtsbildung, w: Freiburger Zeitschrift für Theologie und Philosophie, 1962, H. 2-3, 135.

13 B. Häring, Moralność jest dla ludzi, Warszawa 1975, 136-137. 
nego prawa Bożego" ${ }^{14}$. Cz. Martyniak sądził, że ,jest to ogół zasad będących normatywnym sformułowaniem psycho-fizycznej natury człowieka” ${ }^{15}$. Ks. J. Piwowarczyk pisał „Prawem natury w ogólnym znaczeniu nazywamy ład, nadany światu w pewnym czasie przez Boga" ${ }^{16}$. M. A. Krąpiec, podając wyśmienitą analizę metafizyczną prawa naturalnego, uczy że ,prawo naturalne jest niczym innym jak rozumną inklinacją ludzkiej natury do współmiernego dla człowieka dobra" ${ }^{17}$. Ks. T. Slipko wreszcie podaje następujące określenie: ,prawo naturalne oznacza zbiór norm imperatywnych, obiektywnych i absolutnych (powszechnych i niezmiennych), które uzdalniają podmioty rozumne do spełniania aktów moralnie dobrych, a unikania złych" ${ }^{18}$.

Mimo wielkiej rozbieżności ujęć w powyższych określeniach prawa naturalnego, trzy cechy są im wspólne: uznanie poznawalności tegoż prawa, oparcie jej na metafizycznie pojmowanej naturze człowieka i pojmowanie owego prawa jako podstawy moralnych powinności człowieka. Gdy chodzi o poznawalność prawa naturalnego Hans Kelsen głosi, że „,wszystkie bez wyjątku twierdzenia, wyrażające treść prawa naturalnego są tezami wiary", gdyż zakładają istnienie Boga, należą więc do teologii i mogą być przyjęte jedynie przez wiarę religijną. Inni myśliciele sądzą, ,że prawo naturalne jako takie może być przedmiotem jedynie filozoficznego poznania, chociażby w najszerszym rozumieniu terminu ,filozofia", w jakim np. używamy go mówiąc o filozofii zdrowego rozsądku „,człowieka z ulicy”, jednoznacznie wskazując „,na niemożliwość innej filozofii prawa jak tylko metafizycznej. Tylko bowiem metafizyczna filozofia prawa jest jego filozofią". Tak twierdzi np. ks. T. Styczeń ${ }^{19}$.

Jeśliby prawo naturalne było przedmiotem tylko filozofii, zachodzi pytanie, czy jest ono poznawalne bezpośrednio przez jakąś umysłową intuicję, czy też pośrednio przez rozumowanie już to $\mathrm{w}$ świetle naczelnych założeń filozofii już to na podstawie danych empirycznych, czy cechy etyczne, takie jak dobro lub zło moralne, będące przedmiotem prawa naturalnego, są nam dane bezpośrednio w jakimś doświadczeniu moralności? Fr. Hutcheson, A. Smith i inni przyjmowali istnienie w człowieku czègoś w rodzaju zmysłu moralnego, który wskazywałby ludziom, jak mają postępować, i który ujawniałby się szczególnie w współczuciu. Inni mówią o intuicji czysto umysłowej, ale różnią się między sobą w poglądach na to, co się w intuicji odsłania: czy tylko dobro samo w sobie, jak

$14 \mathrm{Cz}$. Strzeszewski, Katolicka nauka społeczna, S. E. I. Paris 1964, 12.

${ }_{15} \mathrm{Cz}$. Martyniak, Moc obowiazujaca prawa a teoria Kelsena, Lublin 1958, 205.

$16 \mathrm{Ks}$. J. Piwowarczyk, Katolicka etyka społeczna, t. I, London 1957, 30.

17 O. M. A. Krąpiec, Człowiek $i$ prawo naturalne, w: Studia Theologica Varsaviensia, 6 (1968), z. 1, 166, uw. 39.

18 Ks. T. Ślipko, Etos chrześcijański, Zarys etyki ogólnej, Kraków 1974, 230.

$19 \mathrm{Ks}$. T. Styczeń, Problem poznania prawa naturalnego, w: Studia Theologica Varsaviensia, 6 (1968), z. 1, 166, uw. 39. 
sądził G. E. Moore, z wykluczeniem dóbr wtórnych, które można poznać wyłącznie empirycznie, gdyż wymagają zbadania do czego dane czynności i dobra służą, i co z nich wynika, - czy też przez intuicję spostrzegamy także, jakie czyny są słuszne, a jakie są niesłuszne - w myśl poglądów głównego przedstawiciela Oksfordzkiej Szkoły Realistów H. A. Pricharda ${ }^{20}$.

Niewątpliwie w oparciu o same tylko dane empiryczne nie można zbudować wiedzy o koniecznych, nieuwarunkowanych, powszechnych i bezwzględnych powinnościach, jakie ma zawierać prawo naturalne, gdyż wiedza empiryczna, jeśli wypowiada się o tym, co być powinno, a jeszcze nie jest, to tylko warunkowo: jeśli zajdą takie a takie okoliczności, przewiduje się, że nastąpią takie a takie zjawiska, np. zaćmienie słońca. Nie można bowiem doświadczyć tego, czego jeszcze nie ma i nie można mieć bezwzględnej pewności, że przyszłe doświadczenia potwierdzą całkowicie dotychczasowe. To też ks. T. Styczeń badając, na jakiej podstawie uznaje się „w sposób konieczny, rzeczowy i powszechny” zasady prawa naturalnego, przyjmuje empiryzm genetyczny przyznając, że wszelki „kontakt poznawczy ma swe źródło w doświadczeniu zmysłowym", ale odrzuca słusznie empiryzm metodologiczny, głoszący, że spostrzeżenie zmysłowe jest jedynym sprawdzianem wszelkiej wartościowej wiedzy o rzeczywistości. Z naciskiem przy tym podkreśla bezpośredniość ujęcia powinności przez umysł, bo „rozumiejąc, czym lub kim jest dany nam $\mathrm{w}$ kontaktach doświadczalnych człowiek, jesteśmy zdolni do nawiązania głębszych kontaktów, niż kontakty spostrzeżeniowo-empiryczne, czyli potrafimy intelektualnie dotrzeć do natury człowieka i w niej wyczytać powszechne, konieczne, nieuwarunkowane powinności, czyli normy prawa naturalnego, a to dzięki intelektualnemu doświadczeniu". Tak więc człowiek ,nawiązuje bézpośredni kontakt poznawczy z samą powinnością, nie zaś z świadomością powinności czy z przeżyciem powinności" ${ }^{21}$.

Intuicjoniści zarzucają daltonizm moralny zwolennikom emotywizmu, naturalizmu oraz eudajmonizmu, przyznającym się, że nie doświadczają ani nie spostrzegają tego bezpośredniego kontaktu poznawczego z bezwzględną powinnością, a ci odpłacają się ze swej strony intuicjonistom pięknym za nadobne przez podejrzenie ich o uleganie złudzeniu. Gdyby ludzie mieli to swoiste doświadczenie, polegające na intuicyjnym poznaniu słuszności lub niesłuszności w stosunku do jakiegoś czynu, gdyby byli zdolni do bezpośredniego kontaktu poznawczego odnośnie do powinności

20 M. Szyszkowska, Dociekania nad prawem natury czyli o potrzebach człowieka, Warsszawa 1972. Książkia ta i liczne artykuły tejże Autorki stanowią ceniny wkkład do poznania dziejów tej nauki.

${ }_{21}$ Ks. T. Styczeń, art. cyt. 122; Antropologia a etyka, w: Zeszyity Naukowe KUL, 13 (1970), z. 4, 35-42. 
moralnych, byliby zgodni przynajmniej w stosunku do podstawowych norm moralnych, takich jak zakaz uśmiercania niewinnych ludzi jeszcze nienarodzonych, cudzołóstwa, kradzieży, kłamstwa itp. Często to, co uchodzi za intuicję etyczną, jest uwarunkowane przez kulturę, nawyki myślowe i zwyczaje, a nieraz stanowi tylko odzwierciedlenie położenia społecznego ludzi w danym okresie czasu i w danym kraju. Niemal wszystkie normy moralne, dotyczące konkretnych sposobów postępowania, bywają podawane w wątpliwość i gdy jednym wydają się intuicyjnie niewątpliwe, drudzy je odrzucają albo wymagają uzasadnienia. Zresztą nie ma sposobu odróżnienia intuicji pewnych od pozornych, by można było dowieść, która intuicja jest trafna, a która pozorna.

Przyznając, że dla zrozumienia treści prawa naturalnego, pojętego jako zbiór norm bezwzględnie i zawsze obowiązujących lub jako odbicie odwiecznego prawa Bożego w naturze ludzkiej, „jedynie metafizyka klasyczna może zapalić zielone światło wstępu metodologicznie prawomocnego poznania", jak się wyraził ks. T. Styczen ${ }^{22}$, wolimy metafizykom pozostawić dociekania nad istotą ludzkiej natury i jej rzekomo bezwarunkowych, powszechnych, koniecznych i bezwzględnych praw, ograniczając się do tego, co na podstawie codziennych, potocznych spostrzeżeń empirycznych, odnoszących się do psychofizycznych cech i skłonności ludzkich, da się w oparciu o jedną przynajmniej najogólniejszą zasadę normatywną, wywnioskować, choćby tylko bardzo ogólnikowo, o tym co, jak i dlaczego człowiek powinien czynić lub nie czynić, by jego postępowanie było naprawdę rozumne. Dlatego, ze względu na powiązanie terminu ,prawo naturalne” z metafizycznym ujęciem natury człowieka i jego wieloznaczność (wszak wyraz „naturalny” oznacza często to, co zachodzi zwyczajnie, normalnie, co nie jest sztuczne, pozorne, oderwane, nadprzyrodzone, co jest istotne itp.), będziemy posługiwali się terminem: „prawo przyrodzone", naśladując o. Jacka Woronieckiego ${ }^{23}$.

Stosując definicję projektywną, wprowadzamy wyrażenie „prawo przyrodzone" tak, by w miarę możności ustalić jego znaczenie bez powoływania się na założenia metafizyczne lub teologiczne, przez pewne zestawienie znaczeń terminów, wyrażających nazwy dostrzegalnych rzeczywistości, a więc zdarzeń, zjawisk; cech, stosunków, słowem: faktów spostrzeganych empirycznie, a więc bezpośrednio, a najczęściej pośrednio przy pomocy zmysłów. Jasne że, w przeciwieństwie do ujęcia metafizycznego, ujęcie empiryczne nie może rościć sobie prawa do określania czegokolwiek w sposób bezwarunkowy, bezwzględnie konieczny i powszechny.

Otóż codzienne spostrzeganie stwierdza, że w przyrodzie istnieją rze-

22 Tamże, 166.

23 O. J. Woroniecki, dz. cyt. 204. 
czy, posiadające pewne dostrzegalne cechy, uzdolnienia i siły. Rzeczy te pozostają w pewnych dających się określić układach czyli stosunkach do innych rzeczy, wyposażonych w takie same lub inne właściwości. Niektóre $\mathrm{z}$ nich są skupione $\mathrm{w}$ zbiorach nieuporządkowanych, w których nie da się stwierdzić jakiejkolwiek prawidłowości w znaczeniu uporządkowania składników zbioru oraz ich sił według jakiejś zasady, wyrażającej względnie stały stosunek do innych zbiorów lub w samym zbiorze, czy w badanej rzeczy. W wielu jednak układach, które możemy nazwać zespołami ${ }^{24}$, da się empirycznie stwierdzić pewną prawidłowość w ich budowie i działaniu, zależną od warunków, w jakich się znajdują, a więc pewne uporządkowanie składników, uzdolnień czy sił, dokonane już to przez ludzi, już to przez „,przypadek” czy raczej przez siły samej przyrody, ukierunkowane przez jej Stwórcę, jak wierzą chrześcijanie, żydzi i muzułmanie. Zasadą takiego uporządkowania może być np. powinowactwo chemiczne pierwiastków czy elektro-magnetyczna siła przyciągania i odpychania. Tego rodzaju uporządkowanie rzeczy oraz prawidłowość w budowie i w działaniu podług dających się wykryć, względnie stałych stosunków spotykamy zarówno w mikroskopijnych układach protonów, neutronów, elektronów itd. w atomy, atomów w cząsteczki i drobiny, cząsteczek w żywe komórki, komórek w tkanki, tkanek w narządy, narządów w ciała roślin i zwierząt, jak i w makrokosmosie gwiezdnych galaktyk, mgławic, planet, w którym sprawdza się np. prawidłowość ciążenia powszechnego, to że ciała przyciągają się z siłą wprost proporcjonalną do iloczynu mas, a odwrotnie proporcjonalną do kwadratu odległości, że stosunek kwadratów czasów obiegu planet dokoła gwiazd jest równy sześcianowi ich średnich odległości od środka tych gwiazd itp.

Taką prawidłowość uporządkowania rzeczy w względnie stałe zespoły podług dającego się określić względnie stałego stosunku nazywamy p r awe m przyrodniczym, a ,prawa ogólne, powszechne, stwierdzające w formie opisowej najogólniejsze prawidłowości w przyrodzie" będziemy nazywali za B. J. Gaweckim ${ }^{25}$ z a s a d a mi przyrody. Najczęściej, ale nie zawsze, tak pojęte prawo przyrody stwierdza istnienie i rodzaj stosunku zależności między jednym czynnikiem zmiennym a innym czynnikiem zmiennym zawsze i tylko wtedy, gdy zmianom jednego odpowiadają w sposób prawidłowy zmiany w drugim. Do praw przyrody dochodzi się najczęściej przez mniej lub więcej uzasadnione domysły czy hipotezy. Uzasadnia się je przez wysnuwanie z nich stwierdzeń, dających się sprawdzić przez uważne spostrzeganie, czyli przez obserwację

24. P. Teilhard de Chardin określa zespół jako „tę szczególną wyższą formę zgrupowania, której cechą charakterystyczną jest związanie w zamkniętą całość o określonym promieniu pewnej stałej liczby elementów" (Środowisko Boże, Warszawa 1964, 172).

${ }^{25}$ B. Gawecki, Zagadnienie przyczynowości $w$ fizyce, Warszawa 1969, 172. 
lub doświadczenie. Prawa przyrody przez to, że w swych sformułowaniach uwzględniają tylko pewne czynniki, a pomijają inne, przedstawiają tylko schematyczny, uproszczony i przybliżony obraz rzeczywistości, podatny do uzupełnień i poprawek $\mathrm{w}$ miarę doskonalenia się pomiarów i metod badań.

Każdy człowiek jest również w szerokim zakresie tworem przyrody i zespołem różnych składników oraz sił psychofizycznych i dlatego, jak każda rzecz na świecie, podlega prawom przyrody. Ale równocześnie w przeciwieństwie do innych tworów przyrody - jest zdolny nie tylko poznawać te prawa i wprzęgać siły przyrody w służbę własnych celów, które sam sobie stawia, ale także potrafi kierować samowolnie swym życiem i postępowaniem, panować nad swymi zmysłami, popędami oraz uczuciami, a przede wszystkim może doskonalić swą własną osobowość, życie społeczności, do której przynależy oraz przyrodę. Jest bowiem istotą wolną, chociaż ta wolność jest ograniczona; nie jest rzeczywistością statyczną ale dynamiczną, czyli zdolną do samourzeczywistniania własnego człowieczeństwa, bo może stawać się coraz bardziej rozumnym i coraz lepszym.

Ale zachodzi pytanie, czy w swym postępowaniu człowiek, będąc wolnym, może postępować całkowicie samowolnie tak, by, w myśl poglądów J. P. Sartre’a i niektórych liberałów, każda osoba ludzka była dla siebie jedynym ustawodawcą, mogła robić co tylko zechce i nadawać swemu życiu taki sens, jaki sama uzna, nie uznając żadnych naczelnych norm postępowania. Otóż, jak słusznie zauważył L. Strauss ${ }^{26}$ : „Jeśli każdy, nawet najgłupszy człowiek, jest sędzią rozstrzygającym o tym, czego wymaga jego samozachowanie, wówczas trzeba by uznać wszystko, co taki człowiek chce uważać za sprawiedliwe". Takie ujęcie prowadzi niewątpliwie do zniewolenia wszystkich ludzi. Z tego powodu Th. Hobbes, wychodząc z założenia, że człowiekiem rządzą te same prawa mechaniczne, które rządzą przyrodą i które utożsamiał z prawem naturalnym, uznał, że każdy człowiek jest egoistą, bo uznaje za dobro jedynie to, co służy jego celom, a za złe to, co się im sprzeciwia, gdyż przyroda nie zna innej miary dobra i zła. Ale ze względu na fakt, że człowiek musi o wszystko walczyć, a ile wywalczy, zależy od jego sił, by uniknąć wojny wszystkich przeciw wszystkim, potrzebna była wyższa siła sprzęgająca mechanizmy jednostek ludzkich $\mathrm{w}$ potężniejszy mechanizm państwa absolutnego, jako przedmiotowego źródła praw i obowiązków. Choć takie ujęcie prowadzi do tyranii, w pewnej mierze podzielają je zwolennicy „czystej teorii prawa" oraz Hans Kelsen ${ }^{27}$ w swej teorii normy fundamentalnej, będącej logicznym warunkiem ważności prawa pozytywnego ale

${ }^{26}$ L. Strauss, dz. cyt. 23.

${ }_{27} \mathrm{Cz}$. Martyniak, dz. cyt 
nie różnym od niego lecz zapewniającym mu większą siłę, posługującą się przymusem. Ale skąd się wzięła ta norma fundamentalna? Na jakiej podstawie obowiązuje? Co jest bezpośrednim źródłem praw i powinności ludzkich? Ustawodawstwo państwowe? Wola Boża? Odwieczne prawo umysłu Bożego? Sama natura ludzka?

Teoretycy prawa naturalnego właśnie w naturze ludzkiej upatrują źródło prawa naturalnego, ale różnia się zarówno w pojmowaniu samej natury jak i prawa, które z niej wyprowadzają. Poglądy te można sprowadzić do trzech kierunków: autonomicznego, heteronomicznego i teonomicznego pojmowania genezy prawa moralnego. Autonomizm, uznający prawo naturalne za wytwór ludzkiej świadomości, ujawniał się już w klasycznych systemach filozoficznych starożytności, takich jak arystotelizm, stoicyzm, epikureizm, a w czasach nowożytnych przede wszystkim u Em. Kanta, który w przekonaniu, że „Dobra wola nie jest dobra ze względu na swoje dzieła ani ze względu na swą zdatność do osiągnięcia jakiegoś zamierzonego celu lecz jedynie przez chcenie" ${ }^{\mathbf{2}}$. Uznał on za moralnie dobre jedynie te czyny, które pochodzą z dobrej woli, a więc takiej, która usiłuje spełnić obowiązek z poczucia powinności zgodnie z kategorycznym imperatywem: ,,postępuj tylko według takiej maksymy, dzięki której możesz zarazem chcieć, żeby stała się powszechnym prawem" 2 .

Za heteronomicznym pochodzeniem prawa naturalnego opowiadają się nie tylko ci, którzy uważają je za nakaz woli Bożej lub za niezmienny porządek narzucony człowiekowi przez przyrodę, ale także ci, którzy uznają je za wynik ewolucji rodu ludzkiego i jego przystosowania się do warunków życia, za skutek rozwoju społeczno-gospodarczego czy uwarunkowania historycznego lub za wspólny mianownik najogólniejszych znanych praw obyczajowych, czy też za wynik kłębiącego się w podświadomości ludzkiej atawistycznego poczucia winy i chęci uwolnienia się od tego urazu przez zakazywanie sobie wszelkich rozkoszy, zwłaszcza seksualnych, jak mniemali freudyści.

Natomiast teonomizm tomistyczny odrzuca zarówno autonomizm jak i heteronomizm w przekonaniu, że w myśl nauki św. Pawła, iż Bóg nie jest czymś zewnętrznym w stosunku do ludzi, gdyż „w Nim żyjemy, poruszamy się i jesteśmy" (Dz. 17, 28) uznaje, że prawo naturalne jest wyrazem nie tyle woli Bożej ile raczej umysłu Bożego, który jest źródłem i prawzorem wszelkiego uporządkowania we wszechświecie, a szczególniej w osobie każdego człowieka. Prawo naturalne, jako uczestnictwo w tym odwiecznym prawie umysłu Bożego, nie jest więc poza ludźmi lecz w nich. Nie jest wprawdzie wytworem woli ludzkiej ale umysło-

28 E. Kant, Uzasadnienie metafizyki moralności, Warszawa 1953, 12.

29 E. Kant, Krytyka praktycznego rozumu, Lwów 1911, 40. 
wym stwierdzeniem pewnego porządku w osobowości człowieka, który potrzeba ująć $\mathrm{w}$ pewne sformułowanie i urzeczywistnić w praktycznym postępowaniu; sformułowanie zaś jest dziełem umysłu ludzkiego, a urzeczywistnienie jest sprawą zarówno rozumu jak i woli ludzkiej oraz wrodzonych człowiekowi skłonności. Sw. Tomasz wywodzi prawo naturalne z ludzkiej natury, którą jednak pojmuje dynamicznie jako to, co jest podłożem rozwijania różnych możliwości, jakie są w każdym człowieku, w kierunku wyznaczonym przez jego rozum, a nie statycznie, jako bezwzględnie niezmienną istotę. Wszak Akwinata miał odwagę powiedzieć: „natura człowieka jest zmienna” ${ }^{30}$. Jeśli się określi istotę człowieka scholastycznie jako „zwierzęcia rozumnego" w znaczeniu jestestwa zasadniczo zdolnego do rozumowania, gdy zdolność ta nie zostanie udaremniona na skutek niedorozwoju systemu nerwowego, choroby psychicznej czy choćby snu, wówczas tę rozumność trzeba uznać za ideał, do którego trzeba się ciągle przybliżać, stając się coraz bardziej rozumnym i tym samym coraz bardziej człowiekiem doskonalącym siebie, społeczność, do której należy, i przyrodę ${ }^{31}$.

Czy w tak pojętym człowieku da się stwierdzić nie tylko taką prawidłowość $\mathrm{w}$ uporządkowaniu składników, uzdolnień i sił, jaką widzimy $\mathrm{w}$ innych tworach przyrody, a zwłaszcza $\mathrm{w}$ zwierzętach, a więc prawidłowość będącą podstawą naukowych praw przyrodniczych, pozwalających na przewidywanie określonych zjawisk i ustalanie pewnych prawideł czy norm, określających jak należy postąpić, by te zjawiska wystąpiły ale także taką prawidłowość w uporządkowaniu uzdolnień i sił w psychofizycznym ustroju każdego człowieka i w całej społeczności ludzkiej, która umożliwiałaby wýznaczenie oraz uzasadnienie podstawowych uprawnień 'oraz powinności wszystkich ludzi jako istot zasadniczo zdolnych do rozumowania oraz opartego na nim dobrowolnego postępowania? Otóż taką prawidłowość, jeśli istnieje, będziemy nazywali prawem przyrodzonym. Tak pojęte prawo przyrodzone nie utożsamia się z prawem przyrodniczym, bo nie utożsamia porządku, wyznaczonego przez przyczynowość sprawczą przyrody, $\mathrm{z}$ porządkiem istniejącym $\mathrm{w}$ osobowości człowieka, wyposażoną $\mathrm{w}$ rozum i wolną wolę, której działanie nie jest wyznaczone przez siły przyrody. Prawa przyrodnicze wyrażają związek konieczny między warunkami jakiegoś zjawiska a ich następstwami. Natomiast $\mathrm{w}$ człowieku, zdolnym do rozumowania, powiązanie przyczynowe między warunkiem koniecznym czy wystarczającym a skutkiem w postaci dobrowolnego działania, zależy przede wszystkim od woli czło-

30 Sw. Tomasz, Summa Theologica, II-II, q. 57, a. 2, ad 1: „Natura autem hominis mutabilis est".

${ }_{31}$ Dokładniej na ten temat: F. W. Bednarski, Dynamiczne ujęcie prawa naturalnego u św. Tomasza z Akwinu, Rzym 1972, 9-27; oraz Fr. Schmölz, Das Naturgesetz und seine dynamische Kraft, Freiburg 1959. 
wieka, choć następstwa tego działania nie zawsze zależą od człowieka. Prawo przyrodzone w tym ujęciu nie utożsamia się ze statycznie pojętym prawem naturalnym $\mathrm{w}$ znaczeniu gotowego zbioru niezmiennych, powszechnych i bezwarunkowych norm moralnych, utożsamia się natomiast zakresowo ale nie treściowo $\mathrm{z}$ dynamicznym ujęciem prawa naturąlnego u św. Tomasza. Utożsamia się zakresowo w tym znaczeniu, że każde tak ujęte prawo przyrodzone jest równocześnie prawem naturalnym w rozumieniu św. Tomasza i odwrotnie. Ale nie utożsamia się treściowo, gdyż nie wszystko, co się da orzec o prawie naturalnym, da się orzec o prawie przyrodzonym, jeśli w jego ujęciu nie uwzględnia się założeń metafizycznych czy teologicznych, jak to usiłujemy uczynić w niniejszej pracy, oczywiście w miarę jak to jest możliwe, bo przecież niektóre założenia metafizyczne są nieuniknione w najbardziej nawet empirycznych naukach, stosujących się przecież do zasad logiki, opartych na założeniach metafizycznych, jak zasada tożsamości, niesprzeczności, przyczynowości itd.

Prawo przyrodzone w powyższym ujęciu, nie utożsamiając się treściowo ani z prawem przyrodniczym, ani z prawem naturalnym, nie przeciwstawia się im, nie jest sprzeczne ani z jednym ani $\mathrm{z}$ drugim, podobnie jạk każdy człowiek nie stanowi przeciwieństwa do przyrody, której jest w pewnym zakresie tworem i składnikiem, niemniej podobnie jak człowiek jest osobliwym składnikiem przyrody, zdolnym panować nad nią przynajmniej $\mathrm{w}$ pewnej mierze — i wprząc ją do swej służby, tak też prawo przyrodzone wnosi nową treść do pojęcia prawa przyrodniczego, wyrażającą potrzebę dobrowolnego działania, jest bowiem bezpośrednio tworem rozumu ludzkiego, porządkującym postępowanie człowieka w jego życiu osobistym i społecznym dla dobra ogólnego zarówno tego zespołu, jakim jest każda osobowość ludzka jak i każde społeczeństwo. Innymi słowy, prawo przyrodzone spełnia ogólną definicję prawa, podaną przez św. Tomasza z Akwinu: „Prawo jest to rozporządzenie rozumu, zmierzające do wspólnego dobra, ogłoszone przez tego, kto ponosi odpowiedzialność za tę wspólnotę" ${ }^{32}$, a taką wspólnotą jest nie tylko społeczeństwo ale także osobowość każdego człowieka złożona przecież z rozmaitych składników, uzdolnień i sił, z tym że odpowiedzialność za tę wspólnotę ponosi każdy człowiek.

Ale czy prawo przyrodzone w takim ujęciu istnieje? Oto pytanie, któremu poświęcimy następny rozdział naszej pracy.

32 Summa Theologica, I-II, q. 90, a. 4. 


\section{ISTNIENIE PRAWA PRZYRODZOINEGO}

Ponieważ prawo przyrodzone w naszym ujęciu utożsamia się zakresowo $\mathrm{z}$ prawem naturalnym $\mathrm{w}$ jego dynamicznym ujęciu przez św. Tomasza z Akwinu, ten kto nie uznaje tegoż prawa, odrzuca również prawo przyrodzone. Do XVIII w. panowała niemal jednomyślność w uznawaniu prawa naturalnego. Jego istnienie przyjmowali: Platon, Arystoteles, Cyceron, wszyscy klasycy teologii katolickiej, a także wielu myślicieli niekatolickich w czasach nowożytnych. Dopiero pozytywizm prawny w XVIII w. zaprzeczył, by istniało jakieś prawo nadrzędne, nie pochodzące od ustawodawstwa państwowego. Niektórzy egzystencjaliści odrzucają prawo naturalne w sposób jeszcze bardziej radykalny, chociaż jak słusznie stwierdza M. Szyszkowska ${ }^{33}$, rolę natury i jej prawa w egzystencjalizmie nawet samego Sartre'a odgrywa powszechność ludzkich warunków i wspólny wszystkim los. Podobnie marksizm, odrzucając istnienie prawa natury $\mathrm{w}$ znaczeniu apriorycznych, niezmiennych, wiecznych praw, przyjmuje istnienie podstawowych, ukształtowanych w ciągu wieków i uznanych powszechnie przez narody cywilizowane norm moralnych, określających ze względu na pewien zespól potrzeb wspólnych ludziom to, co dla nich jest dobrem i ma wartość, służąc zaspokojeniu ich potrzeb.

W naszym projekcyjnym ujęciu prawa przyrodzonego, pomijającym założenia metafizyczne i teologiczne, odróżniliśmy trzy związane z sobą czynniki: a) swoisty ustrój psychofizyczny ludzi jako podmiot tego prawa, b) prawidłowość w uporządkowaniu uzdolnień i sił jako jego istotę, c) zasadę tego uporządkowania w postaci ukierunkowania tychże sił, umożliwiającą określenie oraz uzasadnienie podstawowych uprawnień i obowiązków ludzi, co stanowi cel tegoż prawa. Udowodnienie empiryczne istnienia tak rozumianego prawa przyrodzonego wymaga stwierdzenia łącznego istnienia tych trzech czynników.

A. Istnienie swoistego dla ludzi ustroju psychofizycznego nie ulega wątpliwości. Nawet samo ciało każdego człowieka mimo bardzo wielu podobieństw do ciał innych zwierząt, zwłaszcza należących do rzędu naczelnych, wykazuje wiele cech dla siebie specyficznych: szczególna budowa ośrodkowego systemu nerwowego, a zwłaszcza mózgu, znamienny układ palców w kończynach górnych, umożliwiający pracę, charakterystyczny układ strun głosowych, ułatwiający mowę, postawa wyprostowana itd. Być może, że te i inne swoiste dla ludzi cechy są wynikiem ewolucji, trwającej miliony, a może nawet miliardy lat, ale jest faktem, że właśnie te cechy umożliwiły rozwój znamiennego dla ludzi ustroju nerwowego i psychicznego. Ludzie, podobnie jak niektóre zwierzęta, po-

${ }^{33}$ M. Szyszkowska, dz. cyt. 102. 
siadają kilkanaście zmysłów, z tym zastrzeżeniem, że niektóre zwierzęta mają zmysły doskonalsze pod pewnymi względami, aniżeli ludzie, np. orły i sokoły mają ostrzejszy wzrok, owady oraz psy mają fantastyczny węch, inne zwierzęta mają bardziej czuły słuch, a niektóre są wyposażone $\mathrm{w}$ jakieś szczególne zmysły, których ludzie nie posiadają, np. nietoperze są wyposażone w coś, co działa jak aparat radarowy. Ale w nas te zmysły są bardziej zharmonizowane $\mathrm{z}$ naszymi potrzebami, których zaspokojenie byłoby bardzo utrudnione albo wręcz niemożliwe, gdybyśmy mieli zmysły tak czułe jak niektóre zwierzęta. Wspólnie z bardziej rozwiniętymi zwierzętami mamy również uzdolnienia, zwane przez scholastyków zmysłami wewnętrznymi, takie jak świadomość łącznie ze zdolnością spostrzegania i skupiania uwagi, pamięć, wyobraźnia, zmysł konkretnej oceny tego co korzystne lub szkodliwe dla ustroju oraz oparte na tym zmyśle instynkty oraz popędy, których przejawami są różne uczucia, jak lubienie i kochanie, pożądanie i radowanie się, nadzieja i śmiałość, bojąźn i strach, nienawiść i wstręt, gniew i smutek. Ale ponadto - $w$ przeciwieństwie do innych zwierząt - ludzie posiadają co najmniej dwa swoiste dla nich uzdolnienia podstawowe, a mianowicie zasadniczą zdolność do rozumowania, gdy ich system nerwowy jest dostatecznie rozwinięty i nie zablokowany przez jakąś chorobę lub sen, oraz zdolność chcenia na podstawie wyboru dokonanego dzięki rozumowi, czyli wolę. Te dwa uzdolnienia umożliwiają ludziom nie tylko wytwarzanie narzędzi i wybitnie rozwiniętą umiejętność posługiwania się nimi, ale także postęp w kulturze, czyli w doskonaleniu siebie oraz przyrody przez społeczną współpracę $\mathrm{z}$ naturą. Brak tego postępu u zwierząt, nawet najbardziej rozwiniętych i tych które stale towarzyszą ludziom, jak np. psy i koty, świadczy, że brak im tych dwóch uzdolnień, mimo że tzw. „inteligencją" niekiedy przewyższają niektórych ludzi, np. matołków, u których zdolność rozumowania i dobrowolnego chcenia została zakłócona na skutek jakiegoś anatomicznego lub fizjologicznego niedomagania.

B. Zasadniczą prawidłowość w uporządkowaniu uzdolnień i sił psychofizycznych w ludziach stwierdzają empirycznie różne nauki biologiczne i psychologiczne, uznając częściowy brak jej u ludzi niedorozwiniętych lub chorych fizycznie czy psychicznie. Niewątpliwie każdy człowiek jest ciałem złożonym z tysiąca kwadrylionów atomów tlenu (63\%), węgla $(20 \%)$, wodoru $(10 \%)$, azotu $(2 \%)$, wapnia $(1,5)$, fosforu, potasu, siarki, chloru, sodu, żelaza, manganu, miedzi, kobaltu, glinu, krzemu i innych (razem około 4,5\%), związanych w około 30 do 60 bilionów komórek, tworzących różne tkanki, z których zbudowane są poszczególne narządy oraz układy szkieletowe, mięśniowe, pokarmowe, krwionośne, moczowo-płciowe, nerwowe, zmysłowe itd., stanowiące jedną organiczną, żywą całość. 
Ale równocześnie każdy człowiek jest scalonym, spoistym i zorganizowanym zespołem nabytych cech, skłonności, popędów; nawyków oraz uzdolnień, wśród których wybija się zdolność do rozumowania i dobrowolnego chcenia.

Gdy chodzi o postępowanie ludzkie, będące przedmiotem prawa przyrodzonego, szczególne znaczenie ma układ przyrodzonych skłonności, których przejawami są odruchy, instynkty, popędy, uczucia oraz wola. Skłonności te dzielimy za św. Tomaszem na wspólne wszystkim istotom żywym, wspólne tylko zwierzętom i ludziom oraz wspólne tylko ludziom - zależnie od przedmiotu tychże skłonności, zmierzających zawsze do zaspokojenia jakiejś potrzeby ${ }^{34}$. Są to skłonności przyrodzone (ale nie koniecznie wrodzone), bo wynikają $\mathrm{z}$ samej struktury osobowości ludzkiej, w przeciwieństwie do „nienaturalnych” skłonności nabytych wskutek jakiegoś uszkodzenia już to embrionu ludzkiego, już to systemu nerwowego $\mathrm{w}$ dzieciństwie lub $\mathrm{w}$ wieku dojrzałym czy starczym, np. z powodu jakiegoś niezdrowego nawyku czy nadużywania napojów alkoholowych, narkotyków czy nawet lekarstw.

Pośród skłonności wspólnych wszystkim rzeczom, a zwłaszcza jestestwom żywym, na czoło wysuwa się dążenie do zachowania bytu osobniczego i gătunkowego; wśród skłonności wspólnych tylko zwierzętom i ludziom to $\mathrm{m}$. in. skłonność do posługiwania się zmysłami oraz różne popędy, które św. Tomasz z Akwinu sprowadza do dwóch podstawowych. Jeden $\mathrm{z}$ nich to popęd do kochania i pożądania tego, co wydaje się dobre, przyjemne lub użyteczne, do wstrętu i odrazy do tego, co wydaje się złe, przykre czy szkodliwe, do radowania się tym, co dobre, miłe i piękne, gdy się to w jakiś sposób osiągnie i do smucenia się, gdy dosięgnie nas jakieś zło, jakaś przykrość czy ból ${ }^{35}$. Popęd ten odpowiada częściowo temu, co Z. Freud nazywał libido, a inni pożądliwością. Drugi podstawowy popęd, zwany przez psychoanalityków agresywnością, można nazwać raczej popędem zdobywczym do walki o dobro trudne do zdobycia, ze złem trudnym do pokonania. Przejawem tego popędu są takie uczucia, jak nadzieja i zniechęcenie w stosunku do dobra trudnego do osiągnięcia, odwaga i bojaźń wobec zła trudnego do pokonania, oraz gniew, gdy takie zło stanie się już faktem dokonanym, ale można je zniszczyć lub udaremnić. Wreszcie skłonności przysługujące tylko ludziom to skłonność do rozumowania w najróżnorodniejszych jego postaciach, do postępowania o-

${ }^{34}$ Summa Theologica, I-II, q. 94, a. 2: „Omnia illa quae homo habet naturalem inclinationem, ratio naturaliter apprehendit ut bona, et per consequens ut opere prosequenda, et contraria eorum ut mala et vitanda. Secundum igitur ordinem inclinationum naturalium, est ordo praeceptorum legis naturae".

${ }_{35}$ Tamże: „Omnes inclinationes quarumcumque partium humanae naturae, puta concupiscibilis et irascibilis, secundum quod regulantur ratione, partinent ad legem naturalem". 
partego na rozumowaniu, a więc do chcenia, oraz skłonności wynikające z tych dwóch naczelnych, jak skłonność do zdobywania wiedzy, sprawności fizycznych, umysłowych i moralnych, do wolności, do posługiwania się mową, do tworzenia dzieł pięknych i odczuwania piękna, do życia społecznego itd.

Skłonności przysługujące wszystkim jestestwom żyjącym na ziemi, a więc także roślinom, opierają się na zasadniczej własności materii żywej, a mianowicie na jej pobudliwości i na przewodnictwie podrażnienia wywołanego na skutek działania podniety zewnętrznej lub wewnętrznej. Ujawniają się $w$ różnych tropizmach roślin, oraz $w$ odruchach u zwierząt i ludzi. Odruchy te są doskonalszą postacią tropizmów dzięki temu, że przewodnictwo podrażnienia dokonuje się $\mathrm{w}$ zwierzętach i. ludziach za pośrednictwem tkanki nerwowej, odznaczającej się większą pobudliwością, niż inne tkanki. Gdy jakaś podnieta zadziała na obwodowe zakończenia neuronu czuciowego, wywołane podrażnienie przenosi się z biegiem nerwu czuciowego w kierunku dośrodkowym, dochodząc do jego połączenia $\mathrm{z}$ neuronem ruchowym, udziela się mu i z biegiem jego włókien dosięga mięśni obwodowych, wywołując ich skurcz, zwany odruchem. Odruchy te są albo bezwarunkowe albo warunkowe czyli nabyte przez różne skojarzenia. Jedne i drugie są jedynym u zwierząt układem sygnałów ale tylko pierwszym u ludzi, którzy posiadają drugi układ w postaci słów i mowy.

Zespół organicznie powiązanych z sobą odruchów w taki sposób, iż wywołanie jednego powoduje $\mathrm{z}$ nieprzepartą siłą sprzężone wystąpienie następnych, stanowi to, co nazywamy instynktem, który skłania zwierzę lub człowieka do natychmiastowego zrobienia tego, co w danej chwili jest konieczne. Dawniej sądzono, że instynkty są wrodzoną reakcją żywego organizmu, dziedzicznie przekazaną, niezmiennie występującą $\mathrm{w}$ tej samej postaci, służącą zachowaniu bytu jednostki lub gatunku. Dziś przeważa bardziej dynamiczne ujmowanie instynktów, uznając tylko ich zaczątkową wrodzoność, którą dalsza wprawa kształci i rozwija, tak by mogły dostosować się do zmiennych warunków i potrzeb życia. Owady posiadają instynkty $\mathrm{w}$ postaci niemal doskonale zdeterminowanej, natomiast kręgowce, a zwłaszcza ludzie, odziedziczają instynkty niezupełnie rozwinięte, podatne na rozwój przez nabywanie doświadczeń, i wyrażające się $\mathrm{w}$ nieokreślonych i dokładnie niewyznaczonych popędach. Znaczna ilość instynktów ujawnia się tylko w pewnych okresach życia, np. instynkt ssania; jeżeli w tych okresach nie mogły się ujawnić, zanikają.

Człowiek, jak każda istota żywa, jest żywym organizmem o całościowym systemie nakładających się procesów cząstkowych, odznaczającym się zdolnością ukierunkowania tych procesów wskutek swej wewnętrz- 
nej organizacji psychofizycznej ku zachowaniu i doskonaleniu życia jednostek i gatunku. Fakt tego ukierunkowania, mający podstawowe znaczenie dla empirycznego ujęcia prawa przyrodzonego, staje się coraz bardziej widocznym w miarę pogłębiania się badań nauk biologicznych. N. Harmann to ukierunkowanie nazywa swoistą celowością biologiczną, tym się różniącą od celowości w ścisłym znaczeniu, że w niej kierunek zależności nie jest określony w sposób jednoznaczny, jak się to dzieje wówczas, gdy człowiek postanawia osiągnąć jakiś cel i dąży do niego. Tego rodzaju celowość Hartmann uznaje za powszechną zasadę życia. Zarówno budowa ciała ludzkiego, jak i wszystkie układy psychofizyczne w osobowości ludzkiej wykazują tę celowość w znaczeniu ukierunkowania i przystosowania ustroju do warunków życia, skoro jego składniki są tak podporządkowane całości oraz wewnętrznie dopasowane, że zapewniają względną trwałość i możność wykonywania określonych czynnoś$\mathrm{ci}^{36}$.

Zwierzęta, reagujące wyłącznie w sposób instynktowny na zmiany zachodzące $\mathrm{w}$ otoczeniu, są przystosowane tylko do podniet stale powtarzających się i mogą żyć tylko w środowisku nie ulegającym zasadniczym zmianom, a gdy takie zmiany nastąpiły, liczne gatunki zwierząt wyginęły, np. ichtiozaury, dinozaury, mamuty itp. Aby jakaś istota mogła utrzymać się przy życiu w zasadniczo zmienionych warunkach musi być zdolną nie tylko do stałych reakcji instynktownych ale także do każdorazowego przystosowania się do zmian $\mathrm{w}$ środowisku, a to wymaga coraz bardziej złożonego mechanizmu w ustroju nerwowym, umożliwiającego powzięcie świadomej reakcji. Warunkiem świadomego myślenia jest zestawienie i porównywanie wrażeń i wyobrażeń obecnych z wrażeniami i wyobrażeniami dawniejszymi, zachowanymi w pamięci, umożliwiającymi przewidywanie, na którym człowiek może oprzeć swój wybór oddziaływania ruchowego i rodzaj swego postępowania.

Wrażenia i wyobrażenia, a nawet pojęcia są zazwyczaj zabarwione uczuciowo, są przyjemne lub przykre, choć nieraz w sposób nieuświadomiony, gdy często powtarzają się lub są oderwane od bezpośrednich potrzeb życia lub gdy natężenie wywołujących je podniet jest zbyt słabe, albo gdy uwagę ześrodkowuje się nie na treści wrażeń, lecz na ich tonie uczuciowym. Spostrzeżenia i wyobrażenia kojarzą się w naszej świadomości z szeregiem innych wyobrażeń odtwórczych oraz ich tonów uczuciowych. Gdy zabarwienie uczuciowe pierwotnego wyobrażenia jest wyłącznie przykre albo wyłącznie przyjemne, następuje zwiększenie jego

${ }^{36}$ R. Kijowski, Próba Nicolai Hartmanna wyeliminowania interpretacji finalistycznej przez ukazanie specyficzności bytów organicznych, w: Studia Philosophiae Christianae, 12 (1976), z. 2, 82. Na temat celowości w przyrodzie zob. art. ks. St. Mazierskiego, Mechanicyzm i finalizm, w: Roczniki Filozoficzne, 22 (1974), z. 3.

11 - Analecta Cracoviensia 
natężenia. Ale jeśli pierwotnemu wyobrażeniu towarzyszy uczucie przykre, a skojarzonym wyobrażeniom uczucie przyjemne, lub odwrotnie, następuje albo osłabienie tonu uczuciowego pierwotnego wyobrażenia albo jego zmiana jakościowa, gdyż jednoimienne uczucia przy kojarzeniu wzmagają się, a różnoimienne zmniejszają swe natężenie lub przechodzą $\mathrm{w}$ inne, np. gdy silne uczucie przykre, towarzyszące skojarzonym wyobrażeniom, jest o wiele silniejsze niż przyjemność, towarzysząca pierwotnemu wyobrażeniu. Często także ton wyobrażenia pierwotnego promieniuje na wyobrażenia lub spostrzeżenia $\mathrm{z}$ nim skojarzone, wywołujące różne nastroje uczuciowe.

Bardzo silne uczucia, wywołane przez spostrzeżenie lub wyobrażenie czegoś przyjemnego względnie przykrego, połączone $\mathrm{z}$ pewnymi przejściowymi zmianami w organizmie (np. w postaci mimowolnych odruchów mięśniowych, zmiany w krążeniu krwi, w oddychaniu) zwiemy wzruszeniami. Wzruszenia, podobnie jak i uczucia spełniają w naszym życiu moralnym bardzo ważną rolę. Zazwyczaj bowiem uczucie przyjemności towarzyszy temu co korzystne, uczucie zaś przykrości temu co szkodliwe dla ustroju, a ponadto każdemu uczuciu towarzyszy pewien popęd do odpowiedniego działania, a mianowicie przyjemność wiąże się z dążnością do utrzymania i spotęgowania tego, co tę przyjemność wywołuje. Natomiast w uczuciu przykrości zawiera się dążność do unikania lub do zniszczenia tego co przykre. Ale nie zawsze to co przyjemne jest korzystne dla życia i nie zawsze to co przykre jest szkodliwe, gdyż te tony uczuciowe, podobnie jak ich praźródła w postaci instynktów, są przystosowane tylko do najczęściej powtarzających się warunków i podniet, będąc bowiem odczynem naszej jaźni na jej wrażenia, wywołane przez wewnętrzne lub zewnętrzne podniety, wyrażają jej stosunek do tych podniet i do otoczenia.

Ale, jak już zauważył W. Biegański ${ }^{37}$ : „,W świadomości naszej nie ma ani samoistnych wyobrażeń, ani samoistnych uczuć, ani takich samych odrębnych popędów, lecz wszystko to razem występuje jako całość, w której dopiero przy pomocy abstrakcji odróżniamy wyobrażenia, uczucia i popędy", przy czym wyobrażenia mają charakter bardziej statyczny, popędy są dynamiczne, uczucia zaś stanowią zabarwienie podmiotowe jednych i drugich. Niekiedy wobec przeświadczenia o bezowocności wysiłków, by zmienić na lepsze to co niezależnie od nas jest źródłem przyjemności lub przykrošci, nie umiemy popędowi nadać odpowiedniego celu oraz ukierunkowania, a wtedy popęd niezaspokojony wywołuje wewnętrzne tarcie i wprowadza urazy oraz zaburzenia do naszej psychiki, lub nawet wywołuje rozstrój nerwowy.

Postępowanie człowieka nie jest tylko wypadkową współzawodnic-

37 W. Biegański, Etyka ogólna, Lwów-Warszawa 1922, 41. 
twa różnokierunkowych popędów, w którym zwycięża popęd budzący większą przyjemność. Skoro bowiem popędy odpowiadają instynktom o niezupełnie wyznaczonym kierunku działania i sposobie oddziaływania na podniety, wobec tego stanowią same przez się dynamiczną dążność nieokreśloną w szczegółach. Dopiero rozum dzięki swej zdolności stawiania celu oraz doboru odpowiednich środków do jego osiągnięcia, potrafi skierować popęd ku określonemu celowi, przekształcając ów popęd $\mathrm{w}$ proste akty woli, składające się na działanie, w jakim stawiamy sobie cele coraz dalsze, osiągalne przez kolejne wykonywanie czynności prostych, z których każdy ma swój bezpośredni cel.

Tak więc rozum jest tą siłą porządkującą popędy, uczucia, wyobrażenia, spostrzeżenia i całe życie człowieka. Dzięki bogactwu wyobraźni i zdolności przewidywania oraz rozwagi w świadomości ludzkiej wytwarza się większe współzawodnictwo różnych skojarzonych popędéów, wymagające namysłu, by nadać właściwy kierunek działaniu przez uświadomienie sobie odpowiedniego celu, który mógłby wzmocnić popęd sprzyjający osiągnięciu owego celu, osłabiając równocześnie przeciwne mu popędy. Ale by takie uporządkowanie popędów było możliwe, jest rzeczą niezbędną, aby ów cel miał zdolność takiego oddziaływania na cały psychofizyczny ustrój człowieka, która by potrafiła zmobilizować wszystkie inne współzawodniczące popędy i skierować je do osiągnięcia owego celu, wyznaczonego przez rozum.

Jak więc widzimy z tego przeglądu mechanizmu postępowania ludzkiego, przeróżne układy cech, uzdolnień, skłonności i sił psychicznych nie są w człowieku zestawione chaotycznie, ale są ściśle z sobą powiązane, uporządkowane i scalone w zwarty zespół, który możemy nazwać osobowością ludzką $\mathrm{w}$ psychologicznym znaczeniu, zakresowo ale nie treściowo utożsamiającą się z zespołem cech ujętych w klasycznej definicji osoby jako ,samoistnego jestestwa rozumnej natury" ${ }^{38}$. Prawidłowość w uporządkowaniu rozmaitych składników osobowości ludzkiej (których H. A. Murray ${ }^{39}$ naliczył 44), ujawnia się w jej strukturze, pojętej jako „organizacja różnych jakościowo, względnie stałych cech, pozostających wobec siebie w określonych stosunkach" ${ }^{40}$. Tę strukturę znamionuje nie tylko zwartość scalenia we wszechogarniający układ i jedność rozmaitych zróżnicowanych składników, ale także pewna samorzutność życiowa i społeczny charakter. Dzięki tej strukturze w ludziach rozwinął się, bardziej niż u zwierząt, system nerwowy, a zwłaszcza mózg, i chociaż z anatomicznego punktu widzenia człowiek jest najmniej przystosowany do środowiska przyrodniczego, w którym nie mógłby życé

38 Summa Theologica, I, q. 29, a. 1.

39 S. Siek, Rozwój osobowości, Warszawa 1976, 15.

40 Tamże. 33. 
mocą samej swej witalnej organizacji jak inne zwierzęta, niemniej właśnie dzięki scalającemu charakterowi rozumu stał się: „najpotężniejszą z istot żywych o największej i najszerszej przestrzeni działania oraz o największym środowisku", jak się wyraził M. Scheler ${ }^{41}$.

Skoro więc uzdolnienia i siły w człowieku są tak powiązane oraz ukierunkowane, że mimo zmiennych warunków zewnętrznych i wewnętrznych dążą do zapewnienia ludziom tego, co jest niezbędne do zachowania i rozwoju (tak osobniczego jak i gatunkowego) i skoro osobowość ludzka jest scalonym oraz uporządkowanym zespołem cech, skłonności oraz uzdolnień nie tylko zmysłowych ale przede wszystkim umysłowych, nie można uniknąć pytania, co jest przedmiotowo-ontologicznym sprzęgłem porządkującym, kształtującym i ożywiającym osobowość ludzką od chwili zjednoczenia plemnika męskiego z żeńską komórką jajową, scalając rozliczne ich składniki w zwarty zespół, rozwijający się z przedziwnym dynamizmem. Religie oraz niemal powszechne przekonanie to sprzęgło upatrują w duszy. Empirycy, nie wchodząc na pole filozofii, opierają się nie na założeniach apriorycznych, ale na samych spostrzeżeniach. Nie mają więc możliwości badania tego, co nie jest ani bezpośrednio, ani pośrednio spostrzegalne. Uporządkowany i sprzężony ustrój różnych cech i sił osobowości ludzkiej jest spostrzegalny tak wewnętrznie przez doświadczenie introspektywne, jak i zewnętrznie przez poznanie przejawów j skutków tego scalenia oraz uporządkowania. Ale samo sprzęgło scalające, porządkujące i kształtujące różne składniki osobowości ludzkiej w żywy organizm człowieka, a więc w osobę, jest niedostępne dla spostrzeżenia i dlatego nie jest przedmiotem, ale co najwyżej postulatem nauk empirycznych, a zwłaszcza psychologii doświadczalnej.

Niemniej gdy chodzi o postępowanie ludzkie, mimo jego uwarunkowań od sprzęgła niedostępnego dla nauk empirycznych, można właśnie na podstawie danych empirycznych stwierdzić istnienie w każdym człowieku pewnej cechy, a raczej siły, ujawniającej się we wszystkich żywych istotach, ale występującej w swoisty sposób w ludziach a mianowicie skłonności do zaspokajania tak cielesnych jak i duchowych potrzeb życia osobistego i społecznego w sposób zgodny $\mathrm{z}$ ustrojem psychofizycznym, a więc rozumnie, czyli pod kierownictwem rozumu i zgodnie z jego zasadami. To dążenie do zaspokajania tych potrzeb jest właśnie tą empirycznie dostrzegalną zasadą prawidłowości w uporządkowaniu poszczególnych składników, uzdolnień i sił tego,żywego zespołu, jakim jest osobowość ludzka. Oczywiście, nie jest ostateczną zasadą, bo wszelkie dążenie jest zawsze zmierzaniem do jakiegoś samoistnego podmiotu działania, jest jego dynamiczną cechą, niemniej jest faktem, że

${ }_{41}$ M. Scheler, Der Formalismus in der Ethik und die materielle Wertethik, Halle 1916, 296. 
właśnie dążenie do zaspokojenia potrzeb jest przejawem tej dynamicznej energii i prę̧żnej siły, która już w embrionie od chwili poczęcia prze ku bezustannemu rozwojowi, kształtuje poszczególne narządy ciała, wyposaża je w różne uzdolnienia, zespala je w jeden organizm i pobudza go do działania. Gdyby człowiek nie miał potrzeb i nie odczuwałby skłonności do ich zaspokajania, nie mógłby rozwijać się ani żyć. Ta skłonność do zaspokajania potrzeb, tkwiąca już w swoistej dla człowieka plazmie rozrodczej, jest siłą w najwyższym stopniu ukierunkowaną ku celowi, którym jest życie i jego doskonalenie, jest więc podstawą tego, co N. Hartmann nazwał swoistą celowością biologiczną, wyjaśniając ją za wzorem K. Darwina teorią doboru naturalnego, jako utrzymania się w walce o byt jednostek najlepiej przystosowanych do warunków życia, oraz teorią mutacji czyli nagłych, samorzutnych zmian gatunkowych w chromosomach komórki zarodkowej.

Jakkolwiekby biologowie tłumaczyli tę prawidłowość w uporządkowaniu i scaleniu zróżnicowanych składników, uzdolnień i skłonności oraz sił w jednolity zespół zwany osobowością ludzką, sam fakt istnienia tej prawidłowości, opartej na tej podstawowej zasadzie, jaką jest skłonność do zaspokajania swoistych potrzeb życia ludzkiego, jest dowodem istnienia prawa przyrodzonego, będącego właśnie desygnatem nazwy tego faktu.

Częsty „rozdźwięk między prawami ludzkimi, a tym co ludzie uważają za słuszne", jest jak się wyraził o. J. Woroniecki ${ }^{42}$, stwierdzeniem konieczności tegoż prawa przyrodzonego.

\section{PRZEDMIOT I CEL PRAWA PRZYRODZONEGO}

Skoro prawo przyrodzone jest prawidłowością w uporządkowaniu psychofizycznego ustroju człowieka, skierowanemu ku zaspokojeniu właściwych mu potrzeb i umożliwiającemu poznanie podstawowych zasad życia moralnego, wskazujących jak należy postępować, by żyć naprawdę po ludzku, a więc rozumnie - i skoro ta prawidłowość nie jest urojeniem ale faktem stwierdzalnym empirycznie, jest jasne, że to prawo przyrodzone nie jest wytworem fantazji lub niesprawdzalnej intuicji, ale jest rzeczywistością przedmiotową, którą każdy człowiek powinien poznać i na podstawie tego poznania sformułować naczelne zasady swego postępowania. Sformułowania te nigdy nie będą doskonałe i ostateczne, bo żaden język nie potrafi wyrazić jakiejkolwiek rzeczywistości, nawet spostrzegalnej przy pomocy zmysłów, w sposób ostateczny i tak dokładny, by nie można było danego sformułowania językowego uzupeł-

42 Woroniecki, dz. cyt. 216. 
nić, poprawić lub udoskonalić stosownie do wymagań zmiennych warunków życia.

Poznanie prawidłowości w uporządkowaniu jakiejkolwiek rzeczy wymaga znajomości przede wszystkim jego przedmiotu oraz celu.

Jak widzieliśmy, empirycznie da się stwierdzić istnienie w ludziach uporządkowania nie tylko poszczególnych składników ciała ludzkiego, ale także zespołu ludzkich sił, skłonności oraz uzdolnień psychofizycznych, umożliwiających rozumne postępowanie oraz rozwój duchowy i postęp w kulturze. Otóż to postępowanie stanowi bezpośredni przedmiot prawa przyrodzonego, a postęp w kulturze jest jego celem.

Postępowanie człowieka jest nieraz wypadkową sił niezależnych od jego woli. Może być niedobrowolne i wymuszone już to przez czynniki zewnętrzne, już to przez stany wewnętrzne, np. przez chorobę psychiczną. Zazwyczaj jednak postępowanie ludzi zdolnych do używania rozu$\mathrm{mu}$ jest dobrowolne, czyli oparte na własnym wyborze i postanowieniu osiągnięcia jakiegoś celu przy pomocy stosownych środków i działań. Prawo przyrodzone ze względu na jego swoistość w człowieku obejmuje bezpośrednio postępowanie dobrowolne, zależne od podmiotu działania; postępowanie zaś niedobrowolne w tej mierze, w jakiej jest przédmiotem postępowania dobrowolnego, np. gdy podaje zasady, jak należy traktować stany psychiczne niezależne od naszej woli lub jak się obchodzić z ludźmi niezdolnymi do używania rozumu. Postępowanie naprawdę ludzkie to takie, które jest zgodne z tym, co zasadniczo wyróżnia ludzi od innych istot, a więc rozumne, a. jest rozumne, gdy jest skierowane do osiągnięcia właściwego celu życia ludzkiego przez stosowanie odpowiednich środków.

$\mathrm{Na}$ postępowanie człowieka składa się wiele czynników, pośród których należy wymienić przede wszystkim a) kierownictwo rozumu, który po pierwsze stawia cel życiu ludzkiemu albo przyjmuje go np. z religii, na podstawie danych dostarczonych przez tradycję, kulturę itp., po drugie rozważa, jakie środki prowadzą do jego osiągnięcia, ocenia, który z nich w danych okolicznościach jest najbardziej odpowiedni, oraz osądza, który $\mathrm{z}$ nich $\mathrm{w}$ danych konkretnych warunkach należy zastosować; b) wolę, która pod kierunkiem rozumu wprzęga siły popędów do urzeezywistnienia tego, co rozum nakazuje, postanawiając osiągnąć ów cel przedstawiony przez rozum jako pewne dobro, które przyciąga wolę, dokonując wyboru środków zaleconych przez rozum i pobudzając do działania siły wykonawcze, by urzeczywistniły postanowienie. Oczywiście mówimy skrótowo, bo przecież to nie rozum myśli, ale człowiek dzięki uzdolnieniu do stawiania sobie celu, wybierania środków i uruchomiania sił wykonawczych. Jaki jest wpływ prawa przyrodzonego na te działania rozumu i woli? 
W przeciwieństwie do statycznego ujęcia prawa naturalnego jako zbioru niezmiennych, bezwarunkowych i powszechnie uznawanych norm, empiryczne ujęcie prawa przyrodzonego podkreśla jego dynamizm, ujawniający się przede wszystkim w ukierunkowaniu przyrodzonych skłonności $\mathrm{ku}$ zaspokojeniu potrzeb życia ludzkiego, osobistego i społecznego, w sposób rozumny, a tym samym ku postępowi w kulturze, a więc w doskonaleniu zarówno każdej osoby ludzkiej jak i przyrody, skoro dążenie do zaspokojenia owych potrzeb jest scalającym czynnikiem żywiołowego nurtu rozlicznych zasobów fizycznej i psychicznej energii ludzkiej w jeden potężny prąd ludzkich działań. Jest bezspornym faktem, że człowiek a) ma różne potrzeby, b) posiada skłonności do ich zaspokojenia przez mniej lub więcej stosowne postępowanie, c) że te potrzeby nie ograniczają się do pożądania dóbr cielesnych, ale obejmują także rzeczy duchowe, jak poznanie zgodne z rzeczywistością, czyli prawdę, miłowanie osób bliskich sobie i pragnienie, by być przedmiotem ich miłości, a przede wszystkim osiągnięcie szczęścia pojętego jako zaspokojenie możliwie wszystkich potrzeb, a więc stanu, w którym niczego nie brakuje z tych rzeczy, które są potrzebne do życia w całej pełni rozumnego, czyli do doskonałości. Skoro zaś celem jakiegokolwiek postępowania jest to, do czego ono zmierza (świadomie lub nieświadomie), można przyjąć, że z empirycznego punktu widzenia celem wyznaczonym przez prawo przyrodzone jest zaspokojenie potrzeb ludzkich w sposób swoisty dla ludzi, a więc rozumnie.

Rozumność działania ludzkiego wymaga uświadomienia sobie hierarchii potrzeb i tym samym podporządkowania celów podrzędnych celom nadrzędnym. Cele bowiem pojedynczych czynności są jakby szczeblami, po których dążymy do jakiegoś ostatecznego celu działania, a więc takiego, który jest celem wszystkich innych celów, a nie środkiem do osiągnięcia czegokolwiek innego. Cele niekiedy bywają zgodne, gdy dążenie do jednego $\mathrm{z}$ nich nie przeszkadza $\mathrm{w}$ dążeniu do innego, ale jest albo środkiem albo pomocą lub warunkiem do jego osiągnięcia; niekiedy jednak bywają niezgodne, gdy dążenie do jednego $\mathrm{z}$ nich uniemożliwia osiągnięcie innego lub przeszkadza w dążeniu do niego.

$\mathrm{Z}$ faktu istnienia prawa przyrodzonego jako prawidłowości w uporządkowaniu wszystkich składników, uzdolnień i sił psychofizycznych, ukierunkowanych $\mathrm{ku}$ zaspokojeniu potrzeb życia ludzkiego, należałoby wnosić, że cele wyznaczone ludziom przez to prawo są zawsze zgodne między sobą. Czy tak jest w rzeczywistości? Niestety, faktyczne cele życia ludzkiego są często niezgodne, nie są wzajemnie uporządkowane, powodując sprzeczne działania. Ponieważ zaś unikanie sprzeczności w działaniu stanowi konieczny warunek wszelkiego uporządkowanego postępowania tak teoretycznego, czyli w myśleniu, jak i.praktycznego, a więc 
$\mathrm{w}$ pracy, prawo przyrodzone, ujawniające się $\mathrm{w}$ należycie ukierunkowanych skłonnościach ludzkich, nie może wyznaczać człowiekowi niezgodnych z sobą celów, choć nieraz zdarza się, że wskutek albo błędnych poglądów osobistych lub środowiska społecznego, nieopanowanych namiętności, wadliwych przyzwyczajeń czy odziedziczonych nawyków: przyrodzone skłonności bywają odwrócone od wyznaczonego im przez prawo przyrodzone właściwego kierunku, którym jest zaspokojanie rzeczywistych potrzeb życia ludzkiego w sposób rozumny, a skierowane do tego co zaspokaja tylko pozorne potrzeby.

Skoro bezpośrednim celem postępowania ludzkiego, wyznaczonym przez prawo przyrodzone, jest zaspokojenie potrzeb życia ludzkiego tak osobistego jak i społecznego, jego zachowanie oraz doskonalenie, jak na to wskazuje zasadniczy kierunek skłonności przyrodzonych, zachodzi pytanie, czy same te potrzeby nie bywają sprzeczne między sobą, czy zaspokajając jedne $\mathrm{z}$ nich, tym samym uniemożliwia się zaspokojenie innych (np. gdy rolnik, chcąc zaspokoić potrzebę zdobycia wiedzy historycznej, poświęca swój czas nauce, a nie pracy na polu i tym samym uniemożliwia sobie i swej rodzinie zaspokojenie pierwotnej potrzeby, jaką jest zdobycie środków do życia, albo gdy stróż pilnujący banku narodowego, zgodnie $\mathrm{z}$ potrzebą zachowania własnego życia, by uniknąć śmierci $\mathrm{z}$ rąk bandyty, umożliwia mu rabunek wielkich sum pieniężnych), koniecznych do udoskonalenia życia społecznego, a niekiedy nawet do jego zachowania.

By rozwiązać tę trudność, należy uświadomić sobie, że prawo przyrodzone nie działa mechanicznie, nie jest zbiorem gotowych przepisów na wszystkie potrzeby we wszystkich okolicznościach, nie ogranicza się w człowieku do ukierunkowania samych tylko instynktów oraz popędów, ale pozostawia człowiekowi dużą autonomię, by sam dobrze rozważył i osądził, co w danych okolicznościach jest ważniejsze i co bardziej rozumne, czy $\mathrm{np}$. zdobywanie wiedzy, czy też zdobycie środków do życia, uniknięcie przedwczesnej śmierci czy uratowanie mienia społecznego, od którego może zależeć życie wielu innych osób. Dlatego konieczne jest uściślenie pojęcia potrzeby, jej odczucia, przedmiotu, zaspokojenia oraz hierarchii potrzeb ludzkich.

Zgodnie z przyjętą metodą definiowania zjawisk przez nazwanie jakiegoś faktu lub zbioru faktów spostrzeganego empirycznie, nazwijmy potrzebą bezwzględnie konieczną rzeczywisty i stwierdzalny stosunek niezbędności pewnych działań lub rzeczy a) do zachowania życia ludzkiego osobowego i społecznego, b) do doskonalenia tego życia; p otr ze bą $\mathrm{z}$ aś względ n ą nazwijmy stwierdzalny stosunek przydatności pewnych działań i rzeczy nie koniecznych do tego celu ale prowadzących do niego, i wreszcie nazwijmy potrzebą urojoną 
to, co ani nie jest konieczne ani przydatne do osiągnięcia tego celu, lecz może nawet szkodliwe, ale się odczuwa wskutek błędnego przeświadczenia, nawyku, nacisku środowiska społecznego, propagandy itp.

Często, ale nie zawsze, potrzeby są odczuwalne przez poszczególne osoby, np. dzieci szkolne nie zawsze odczuwają potrzebę uczenia się matematyki, historii itp. Nie można więc potrzeb utożsamiać z odczuciami, skoro potrzeby są raczej przedmiotem odczuć. Nieraz człowiek nie odczuwa nawet najbardziej podstawowych potrzeb, np. głodu, gdy znajduje się pod wpływem działania narkotyku, albo — jak słusznie mówi A. Siciński - „o potrzebach kulturalnych mówi się często dopiero wtedy, gdy one nie 'występują' tzn. nie są odczuwane ${ }^{43}$. Potrzeby ludzkie bowiem nie są statyczne, lecz ulegają różnym zmianom zależnie od warunków życia. Człowiek wprawdzie jest zawsze i wszędzie istotą zasadniczo zdolną do rozumnego myślenia, chcenia i postępowania, ale ta jego rozumność na tej ziemi nigdy nie jest w pełni urzeczywistniona, bo człowiek zawsze może się doskonalić. Zaspokajając istniejące już potrzeby, wzbudza nowe, domagające się coraz doskonalszego ich zaspokojenia.

Przedmioty rzeczywistych potrzeb ludzkich, zdolne zaspokajać je, nazywamy wartościami przedmiotowymi, natomiast przedmioty rzeczywistych lub pozornych potrzeb ludzkich, oceniane przez ludzi jako zdolne zaspokoić owe potrzeby, nazywamy wartościami podmiotowymi lub subiektywnymi. Jasne więc, w takim ujęciu, że wartości przedmiotowe, mogą być równocześnie ale pod innym względem podmiotowymi i odwrotnie. Wartości przedmiotowe są, a podmiotowe mogą być d o br a mi, czyli tym, co zdolne jest wzbudzać pożądanie z tym zastrzeżeniem, że nie dlatego są dobrami, iż są pożądane, tylko dlatego są pożądane, bo są dobrami. Jeśli takim dobrem nie jest jakiś byt samoistny ale postępowanie pod każdym względem rozumne, a więc naprawdę godne pożądania, albo gdy jest sprawnością $w$ takim postępowaniu, wówczas mamy dobro moralne, którego przeciwieństwem jest $\mathrm{z} \nmid$ o moraln e czyli postępowanie, które przynajmniej pod jednym względem jest nierozumne $\mathrm{w}$ tym znaczeniu, że sprzeciwia się temu co stanowi sens życia ludzkiego. Pojęcie dobra jest nadrzędne w stosunku do pojęcia wartości, gdyż wszystko, co przedmiotowo jest wartością, jest równocześnie pewnym dobrem, ale nie wszystko co jest dobrem stanowi wartość dla ludzi: niekiedy jest bezwartościowe, przynajmniej w mniemaniu ludzi, którzy nie odczuwają potrzeby tego dobra. W a r t o ści a mi bowiem w języku potocznym nazywamy rzeczy, działania oraz cechy oceniane przez ludzi jako zdolne zaspokajać ich potrzeby cielesne, umysłowe, estetyczne, moralne, religijne (Tzw. wartości u-

${ }^{43}$ A. Siciński, Pojęcia „potrzeby” $i$ „wartości” $w$ świetle koncepcji systemu, w: Studia Filozoficzne, 12 (1976), 44. 
jemne czy negatywne názywamy wartościami o tyle, o ile przyczyniają się nie do zaspokojenia rzeczywistych potrzeb ale do ich spotęgowania i nasilenia).

Tak pojęte wartości są przedmiotem wartościowania, które wyrażamy w oce n a ch czyli twierdzeniach, że coś (np. rzecz, fakt, cecha) jest dobre lub złe (fizycznie lub moralnie), słuszne lub niesłuszne, piękne lub brzydkie, użyteczne lub szkodliwe, przyjemne lub przykre, konieczne lub zbędne, łatwe lub trudne, słabe lub silne itp. Nie tylko przedmioty potrzeb mogą być wartościowe, ale także same potrzeby mogą być niekiedy odczuwane i wartościowane, niekiedy odczuwane ale nie wartościowa๑, a czasami ani wartościowane, ani odczuwane. Jasne, że to, co uchowartość u jednych ludzi, nie musi być wartością dla innych ludzi, , co jest wartością dodatnią dla jednych, a nawet dla tych samych pewnych okolicznościach staje się wartością ujemną, "jak dla innych innych okolicznościach, np. niektóre lekarstwa.

Prawo przyrodzone nie daje gotowej recepty, która by mogła służyć do bezpośredniego oceniania i wartościowania poszczególnych potrzeb. Podaje tylko najogólniejsze wytyczne do takiego wartościowania w postaci skłonności przyrodzonych oraz najogólniejszej zasady; że dobro należy czynić a zła nie należy czynić. Rozum zaś w oparciu o przyrodzone skierowanie owych skłonności, o dane doświadczenia i nauk empirycznych, ma osądzić, co w danych konkretnych warunkach jest naprawdę dobre, lepsze czy najlepsze, i tym samym co należy wybrać i. urzeczywistnić.

Potrzeby ludzkie są nie tylko jednostkowe, czy raczej osobowe, ale także społeczne, gdyż człowiek właśnie dlatego, że jest istotą zasadniczo rozumną, czy raczej zasadniczo zdolną do rozumnego postępowania, jest tym samym istotą społeczną, gdyż rozum mu mówi, że tylko w społeczeństwie może się rozwijać i doskonalić w kulturze oraz stawać się rozumnym. Każdy człowiek jest cząstką tej wielkiej całości jaką jest ludzkość. „Każda część zaś z natury swej jest dla całości”, mówi św. Tomasz z Akwinu ${ }^{44}$. „Otóż każda pojedyncza ostoba ma się tak do całej społeczności jak część do całości", Dlatego potrzeby społeczeństwa są potrzebami składających się na nie osób, a w pewnej mierze rzeczywiste potrzeby osób są potrzebami społeczeństwa w myśl pięknych słów św. Pawła Apostoła (1 Kr 12, 20-21): „Wprawdzie liczne są członki, ale jedno ciało. Nie może więc oko powiedzieć ręce: nie jesteś mi potrzebna, albo głowa nogom: Nie potrzebuję was".

Przedmiotem potrzeb tak osobowych jak i społecznych są nie tylko rzeczy materialne zewnętrzne, jak powietrze, pokarm, odzież, mieszka-

${ }^{44}$ Suma Teologiczna II-II, q. 64, a. 2. Przekład F. W. Bednarskiego, London 1963, t. 18, Sprawiedliwość. Zob. komentarz tłum. 306. 
nie, pieniądze, różne narzędzia, oraz wewnętrzne jak zdrowie, siły fizyczne, zwinność i piękność ciała, ale przede wszystkim dobra duchowe, jak sprawności umysłu i woli, takie jak inteligencja, wiedza i nauka, mądrość, umiejętność tworzenia dzieł pięknych czyli sztuka, a przede wszystkim sprawności moralne, takie jak roztropność, sprawiedliwość, patriotyzm, pietyzm wobec rodziców i krewnych, szacunek dla osób godnych poważania, wdzięczność, posłuszeństwo dla przełożonych, ofiarność, prawdomówność, męstwo, cierpliwość, wielkoduszność, wytrwałość, stałość, umiarkowanie, czystość, trzeźwość, skromność itp. Każdy z tych terminów, przynajmniej w etyce tomistycznej, nie jest abstrakcją, ale nazwą rzeczywistych sprawności, a więc cech, których przejawy są spostrzegalne empirycznie przynajmniej w sposób pośredni, np. sprawiedliwość jest nazwą stwierdzalnego empirycznie u wielu ludzi sprawnego oddawania każdemu tego, co się jemu należy, np. długu; roztropnośé jest nazwą faktu, spotykanego dość często u ludzi, a polegającego na tym, że niczego nie robią bezmyślnie, ale zastanawiają się nad tym, co i dlaczego należy zrobić, jakich środków można do tego użyć, który z nich w danych okolicznościach jest najbardziej odpowiedni, a wybrawszy ów środek, umiejętnie stosują go $\mathrm{w}$ praktyce. Podobnie można powiedżieć o każdej sprawności moralnej, gdyż nazwy każdej z nich wyrażają rzeczywistość, której przejawy są spostrzegalne empirycznie i dadzą się odróżnić od przejawów przeciwstawnych im wad. Nie, są to więc nazwy bardziej abstrakcyjne, niż np. takie wyrazy jak ruch, energia, siła, ciepło. Ich ogólność nie utożsamia się z ich abstrakcyjnym ujęciem.

Potrzeby cielesne to takie, które odnoszą się do rzeczy niezbędnych lub przydatnych do życia, zdrowia i sprawności ciała ludzkiego. Natomiast potrzeby duchowe odnoszą się do rzeczy, względnie działań ludzkich oraz przysposobienia do działań, umożliwiających rozwój kultury nie tylko fizycznej i gọpodarcżo-technicznej, ale także umysłowej, artystycznej i przede wszystkim moralnej w poszczegôlnych osóbach i społeczeństwach. Bez zaspokojenia tego rodzaju potrzeb życie społeczne, a niekiedy poszczególnych osób, byłoby niemożliwe, jak świadczy historia i socjologia, a zawsze ulegałoby zakłóceniom w swoim rozwoju.

Wszystkie potrzeby życia ludzkiego są z sobą sprzężone, „nie chodzą luzem", podobnie jak i skłonności do ich zaspokojenia. Stanowią jedną organiczną, hierarchicznie uporządkowaną całość: zaspokojenie potrzeb cielesnych umożliwia zaspokojenie potrzeb umysłowych oraz moralnych i wszystkich innych, a bez zaspokojenia potrzeb duchowych życie tak osobowe jak i społeczne byłoby często do tego stopnia utrudnione, że zaspokojenie nawet samych potrzeb cielesnych byłoby niemożliwe. Gdyby np. ogół ludzi nie zaspokajał społecznej potrzeby sprawiedliwości, i nie kierował się jej poczuciem, człowiek dla człowieka byłby już nie 
wilkiem, ale katem i ludzie wyginęliby, mordując się wzajemnie. Chociaż więc sprawiedliwość wydaje się pojęciem abstrakcyjnym, niedostępnym dla spostrzegania empirycznego, niemniej to pojęcie wyraża empirycznie sprawdzalny fakt, że ludzie na ogół oddają każdemu, co się jemu należy, że wielu z nich czyni to sprawnie, czyli łatwo, ochoczo i z przyjemnością. Tak więc sprawiedliwość, podobnie jak każda inna sprawność moralna, umysłowa czy fizyczna, wyraża pewną rzeczywistość empirycznie stwierdzalną jako fakt, a brak tego rodzaju sprawności powoduje wielkie zakłócenie życia społecznego w postaci kradzieży, morderstw, wojen, oszustw itp. Nie są to więc nazwy puste, gdyż mają desygnaty $w$ postaci pewnych rzeczywistych cech ludzkich, podobnie zresztą jak ich przeciwieństwa w postaci wad.

Pośród wszystkich potrzeb hierarchicznie najważniejsze są potrzeby moralne, nawet $\mathrm{z}$ empirycznego punktu widzenia, bo historycznie i socjologicznie można wykazać, że społeczeństwa, w których moralność stoi nisko, w których mnożą się morderstwa, rabunki, kradzieże, występki seksualne itp. ulegają szybko rozpadowi, a jednostki tracą życie lub zdrowie bez porównania częściej, niż w społeczeństwach, w których ludzie są roztropni, sprawiedliwi, dzielni, umiarkowani, jedni drugim życzliwi. Wyższość jednak potrzeb i wartości moralnych, a tym samym przyrodzonych skłonności do nich, wynika przede wszystkim stąd, że one zasadniczo stanowią o prawdziwym dobrobycie $\mathrm{w}$ znaczeniu dobrego bytu tak społeczeństw, jak i poszczególnych osób, bo tylko przez posiadanie wartości moralnych byt każdego człowieka i każdej społeczności staje się na prawdę dobrym, podczas gdy inne wartości czynią go dobrym tylko pod pewnym względem, np. sprawność w grze czyni człowieka dobrym muzykiem ale nie zawsze dobrym człowiekiem.

Przyrodzone skłonności, ukierunkowane w każdym człowieku ku rozumnemu zaspokajaniu potrzeb życia ludzkiego, wprawdzie nie narzucają mu określonych celów działania ale podsuwają je rozumowi, by rozważył i rozsądził, które z tych potrzeb należy uznać za nadrzędne, a które trzeba im przyporządkować, które zaspokoić od razu i bezpośrednio, a które stopniowo tak, by cele pojedynczych czynności były jakby szczeblami, po których moglibyśmy dążyć do jakiegoś bezwzględnie ostatecznego celu. Jedną $\mathrm{z}$ zasadniczych potrzeb życia ludzkiego, jako istot zasadniczo zdolnych do rozumnego postępowania, jest konieczność uporządkowania działań, a tym samym podporządkowania środków i celów podrzędnych celom nadrzędnym, a przede wszystkim bezwzględnie ostatecznemu celowi całego życia ludzkiego. Czy taki cel istnieje? Z empirycznego punktu widzenia jest niewątpliwym faktem, że wszyscy ludzie pragną zaspokoić w miarę możności wszystkie swe potrzeby i dążą do tego świadomie lub nieświadomie, skutecznie lub bezskutecznie, ro- 
zumnie lub nierozumnie. Taki zaś stan, w którym by wszystkie potrzeby życia ludzkiego zostały zaspokojone, w którym więc nie brakowałoby niczego z tych rzeczy, których rozum ludzki wymaga, jedni nazywają doskonałością, inni szczęśliwością zależnie od tego, czy uwzględniają głównie dynamiczny czy statyczny charakter tego stanu. W ujęciu dynamicznym ów stan pojmuje się jako najdoskonalsze w miarę możności życie, a więc działanie, w ujęciu statycznym natomiast wysuwa się przede wszystkim zadowolenie, radość czy nawet rozkosz, a więc uczucia będące następstwem osiągnięcia ostatecznego celu, czyli doskonałości. Św. Tomasz z Akwinu zespala doskonałość ze szczęśliwością, twierdząc, że „szczęśliwość to ostateczna doskonałość człowieka. Otóż każde jestestwo jest o tyle doskonałe, o ile jest istotnością (aktem)... a działanie jest ostateczną istotnością działającego jestestwa" ${ }^{45}$.

Ludzie najczęściej upatrują szczęścia w powodzeniu, a więc w pomyślnym urzeczywistnieniu celów i zamiarów, któremu towarzyszy wolność od cierpień, zadowolenie i rozkosz (hedonizm), choć wiadomo, że na tej ziemi wyłączna rozkosz jest w ogóle niemożliwa, bo zadowolenie i niezadowolenie, przyjemności i przykrości stanowią stany uczuciowe bardzo względne i zależne wzajemnie od siebie: każda przyjemność wzmaga się, gdy występuje bezpośrednio po cierpieniu i przeciwnie ból bardziej odczuwamy po doznaniu uczucia radości czy przyjemności. Wiadomo także, że rozkosz czy trwały stan przyjemny z biegiem czasu traci na swym natężeniu, wywołuje znudzenie i tym samym powoduje uczucie przykrości. To też nawet J. S. Mill, czołowy przedstawiciel utylitaryzmu społecznego i zasady, że najwyższym ideałem jest szczęście jak największej liczby osób, przyznał, że: „lepiej jest być niezadowolonym człowiekiem, niż szczęśliwym prosięciem i lepiej być nieszczęśliwym Sokratesem, niż zadowolonym głupcem" "46. Tak więc uznanie szczęśliwości w znaczeniu trwałego stanu radości czy rozkoszy za ostateczny cel życia ludzkiego jest wielkim nieporozumieniem, skoro tego rodzaju stany uczuciowe są następstwem osiągnięcia jakiegoś celu, stanowiącego zaspokojenie potrzeb życia ludzkiego, a tym samym nie mogą być uznane za ostateczny cel życia, choć często ludzie tak postępują, jakby uważali je za swój najwyższy cel, podobnie jak inni żyją w ten sposób, jakby zdobycie pieniędzy, kariery, powodzenia, sławy było najwznioślejszym ich ideałem.

Cóż więc z empirycznego punktu widzenia jest tym ostatecznym celem życia ludzkiego, wyznaczonym przez prawo przyrodzone?

45 Suma Teologiczna, I-II, q. 3, a. 2. W przekł. Bednarskiego, t. 9, Londyn 1963, 61 .

${ }_{46}$ Por. T. Kotarbiński, Utylitaryzm $w$ etyce Milla $i$ Spencera, Kraków 1915, 32. 
Fakt, że wszyscy ludzie pragną zaspokoić wszystkie swe potrzeby $\mathrm{w}$ miare jak to jest możliwe i że w tym kierunku prą ich przyrodzone skłonności, wskazuje, że to zaspokojenie jest ich rzeczywistym celem, ale stan, w którym by wszystkie potrzeby życia ludzkiego, możliwe do zaspokojenia, zostały rzeczywiście zaspokojone, czyli szczęśliwość, to stan nie osiągalny $w$ całości na tym świecie. Ani historia przeszłości, ani socjologia teraźniejszości nie zna człowieka, którego wszystkie potrzeby zostały zaspokojone. Nikt nie był i nie jest wolny od różnych przykrości czy cierpień i śmierci, nikt nie poznał wszystkiego co chciałby poznać, nikt nie był kochany przez wszystkie bliskie mu osoby tak jak by chciał być kochanym. Czyż więc szczęśliwość oraz doskonałość to utopie czy mrzonki, pozbawione wszelkich podstaw nadziei w możliwość choćby tylko przybliżonego urzeczywistnienia? Czy całe życie ludzkie jest tylko bezsensownym dążeniem do nieosiągalnego celu i beznadziejną gonitwą za ułudą, zgodnie z powiedzeniem J. P. Sartre'a, że „,absurdem jest żeśmy się urodzili, i absurdem, że umrzemy”, a jeszcze dosadniej wypowiedział to autor biblijnej księgi Eklezjastesa Kohelet: „Cóż przyjdzie człowiekowi z całego trudu, jaki zadaje sobie... a oto wszystko to marność i pogoń za wiatrem" $(1,1,14)$.

By rozwiązać tę trudność H. Spencer zawężył pojęcie doskonałości do całkowitego przystosowania się człowieka do warunków otoczenia. W przekonaniu, że rozwój ludzkości idzie po takich samych szczeblach co każda inna ewolucja, a mianowicie po drodze scalania; różnicowania i coraz ściślejszego wyznaczania, które ujawnia się w coraz doskonalszym celowaniu (w znaczeniu dążenia do takich celów, które możliwie najzupełniej zabezpieczają pełnię życia zarówno osobniczego jak i gatunkowego), Spencer uznał doskonałe przystosowanie się ludzi i wynikającą z niego równowagę między nimi a przyrodą za czynnik umożliwiający pełnię życia ludzkiego, która w oddalonej przyszłości może być urzeczywistniona. Ale pogląd Spencera jak'oby przystosowanie się do warunków otoczenia było takim celem, nie zgadza się z doświadczeniem, które stwierdza, że ludzie stärają się raczej przystosować środowisko do własnych wymagań i potrzeb, niż przystosować siebie samych do otoczenia. Zresztą doskonałość życia nie jest cechą przyrodniczą, ale etyczną i zazwyczaj nie przystosowanie się do warunków bytu, ale przeciwstawianie się im jest bodźcem i dźwignią postępu, bo pobudza do wytwarzania tych wartości, które są niezbędne do rozwoju kultury.

J. M. Guyau oraz Fr. Nietzsche upatrywali najwyższy cel ludzi w spotęgowaniu życia, jego rozlewności i natężenia, obalającego wszelkie prawa, znoszącego wszelkie granice między dobrem a złem i zmierzającego do przetworzenia człowieka w nadczłowieka. Uznając, że jedynie życie 
ma bezwzględną wartość, Nietzsche głosił, że wolność należy się tylko temu, kto posiada dość siły, by ją sobie zapewnić, że ludzie nie są równi, ale lepsi i gorsi zależnie od tego, ile mają w sobie sił, jak to już przedtem uczył Th. Carlyle, że silniejsi są lepsi i dlatego mają prawo do każdej rzeczy, słabsi winni im ustępować, a ze zwycięstwa, z powodzenia i z sił można wnosić o słuszności: kto zwycięża ten ma słuszność! Do czego ta teoria, którą hitlerowcy próbowali urzeczywistnić, doprowadziła w czasie ostatniej wojny światowej, nie potrzeba dowodzić.

Utylitaryści, z wspomnianym już J. S. Millem na czele, widzą ostateczny cel życia ludzkiego w możliwie największym dobrobycie jak największej liczby ludzi ze względu na to, że szczęście czy nieszczęście ogółu odbija się na jednostkach. Stąd uczynki ludzi są dobre, jeśli pociągają za sobą szczęście innych, a złe w miarę nieszczęścia, które mogą spowodować. Jedyny więc miernik słuszności i godziwości utylitaryści widzą w dobru następstw postępowania dla społeczeństwa (w przeciwieństwie do solipsyzmu K. Schmidta-Stirnera, który w ogóle odrzucał pojęcia norm moralnych, dobra i zła jako bezsensowne i twierdził, że miejsce państwa powinien zająć związek egoistów, z których każdy mógłby robić co tylko zechce). Teoria utylitarystów prowadzi do uznania za dobre np. morderstwa dokonanego na osobie niewinnej, jeśliby ono mogło przynieść korzyść wielu innym ludziom.

Dlatego zwolennicy etyki deontologicznej, a zwłaszcza E. Kant i G. E. Moore, uznali, że istotę moralności należy upatrywać nie w następstwach postępowania, ale w jego pobudkach i motywach. Takim motywem, według Kanta, ma być szacunek dla prawa, pochodzącego od rozumu i porządkującego popędy oraz uczucia ludzkie, tak by człowiek kierował się, w swoim postępowaniu poczuciem bezinteresownego spełniania obowiązku. To prawo moralne, w ujęciu Kanta, ma charakter czysto formalny, jest bez jakiejkolwiek treści wyznaczającej przedmiot pożądania za pośrednictwem skłonności oraz uczuć; nie zawiera też żadnych konkretnych norm czy przepisów. To prawo moralne, jako kategoryczny nakaz rozumu, nie może być uzależnione od jakiejkolwiek zgodności postępowania z jakimś innym celem, którym nie byłaby sama powinność. Motywem zaś powinności ma być wyłącznie poszanowanie prawa, a nie osiągnięcie jakiegoś celu, np. szczęścia. Tak więc deontologiczny kierunek etyki przeciwstawia się kierunkowi teologicznemu, który sprawdzian godziwości i moralności postępowania widzi w zgodności z ostatecznym celem człowieka, jakim według hedonistów jest rozkosz, według utylitarystów szczęście jak największej liczby ludzi a według perfekcjonizmu eudajmonistycznego doskonałość życia ludzkiego tak osobowego, jak i społecznego, z tym że tę doskonałość Platon upatrywał $\mathrm{w}$ urzeczywistnieniu najwyższej idei dobra, Arystoteles i stoicy w mąd- 
rości, chrześcijanie w zjednoczeniu z Bogiem jako najwyższą Prawdą, nieskończonym Dobrem i najbardziej zachwycającym Pięknem.

Czy uznanie zaspokojenia potrzeb życia ludzkiego za cel prawa przyrodzonego nie jest utylitaryzmem etycznym, skoro za miarę godziwości czynu ludzkiego uzraje osiągnięcie celu, a nie jego wewnętrzną wartość i skoro wartość postępowania należy oceniać podług tego, czy jest ono samo w sobie d'obre czy złe, słuszne lub niesłuszne, godziwe czy niegodziwe, a nie podług samych tylko jego następstw, choćby tym następstwem było osiągnięcie jakiegoś ostatecznego celu? W. D. Ross oraz R. B. Brandt $w$ druzgocącej krytyce utylitaryzmu czynów ${ }^{42}$, słusznie podkreślili, że w myśl tej teorii wolno byłoby dopuszczać się czynów egoistycznych, a nawet zbrodniczych ilekroć ich sprawca odniósłby jakąś istotną korzyść ze swego postępowania, a równocześnie zwiększyłby dobro ogółu lub zmniejszyłby powszechne zło choćby tylko przez zwiększenie własnego dobra.

$\mathrm{Z}$ empirycznego punktu widzenia, zaspokojanie potrzeby życia ludzkiego jest niewątpliwie użyteczne, a postępowanie, które je zaspokaja w sposób rozumny, a więc zgodnie z tym co wyróżnia człowieka od innych jestestw, jest dla człowieka dobre. Ale rozumność postępowania ludzkiego wymaga nie tylko jego użyteczności w szerokim znaczeniu tego słowa, a więc także jako warunku doskonalenia moralnego życia ludzkości, lecz także uwzględnienia wszystkich okoliczności tego postępowania (okoliczności podmiotu, przedmiotu, celu osobistego, środków, sposobu, czasu, miejsca, następstw), nie ograniczając się do samych tylko następstw, jak to czyni utylitaryzm, uwzględniając przede wszystkim wewnętrzną wartość moralną postępowania. Czy jednak, przyjmując zasadę naczelną, że „dobro należy czynić a zła należy nie czynić i określając jako dobro to, co zaspokaja potrzeby ludzkie w sposób rozumny nie stajemy na gruncie utylitaryzmu choćby perfekcjonistycznego? Niewątpliwie byłoby tak, gdybyśmy twierdzili, że tylko to, co zaspokaja potrzeby życia ludzkiego jest dobre i tylko to, co je uniemożliwia jest złe, czyli gdybyśmy empiryczne ujęcie dobra moralnego uznali za jedyne i wystarczające do kierowania życiem ludzkim, a tego bynajmniej nie twierdzimy i nie uznajemy, gdyż to byłoby właśnie sprzeczne z ujęciem empirycznym, które nigdy nie przesądza o tym, co leży fcza zasięgiem spostrzegania. Zresztą samo sformułowanie, że dobrem jest to co rozumnie zaspokaja potrzeby życia ludzkiego, wskazuje na to, że jeśli skądinąd wiemy, że życie ludzkie ma jakiś wyższy, empirycznie nie sprawdzalny cel, np. zaspokajający potrzebę umysłu

47 W. D. Ross, The Right and the Good, Oxford 1930, roz. II; R. B. Brandt, Toward a Credibile Form of Utilitarianisme, w: Morality and the Langauge of Conduct, Detroit 1963, 110. 
ludzkiego, by bezpośrednio poznać najwyższą Prawdę, potrzebę woli ludzkiej, by być podmiotem i przedmiotem miłości nieskończonego Dobra czy potrzebę serca ludzkiego, by zachwycać się niepojętym Pięknem Bytu Bożego, postępowanie ludzkie byłoby nierozumne, jeśliby było niezgodne z tym celem naczelnym, niedostępnym dla empirycznego ujęcia, ale przyjętym przez wiarę religijną. Nasze ujęcie jest więc teologiczne, ale nie utylitarystyczne lecz eudajmonistyczne, idące $\mathrm{w}$ kierunku, wytyczonym przez Platona, Arystotelesa, a zwłaszcza przez św. Tomāsza z Akwinu.

Sw. Tomasz, wychodząc z założenia, że dobro jest czymś godnym pożądania, stwierdza, że: ,godnym pożądania jest coś o tyle, o ile jest doskonałym, gdyż każde jestestwo pożąda swej doskonałości" ${ }^{48}$. Nie dlatego więc coś jest dobrem, że jest pożądane, jak już wspomnieliśmy, albo że zaspokaja potrzeby, że zachowuje, rozwija i doskonali byt. To że dobro stanowi przedmiot pożądania i cel określonego dążenia jest następstwem posiadania przez ten przedmiot zdolności doskonalenia. Można więc, za ks. H. Jurosem ${ }^{49}$ określić dobro ,jako to co będąc doskonałe w sobie, posiada zdolność doskonalenia innego bytu, który $\mathrm{z}$ tej przyczyny pożąda je jako cel".

Zasadniczo więc dobrem dla każdego bytu, a więc także dla takiego zespołu bytćw, jakim jest każda ludzka społeczność, jest to co stanowi doskonałość tego bytu względnie zespołu, ubocznie zaś to co jest warunkiem lub następstwem jej osiągnięcia. Doskonałość zaś może być dwojaka: podstawowa i wtórna. Podstawową doskonałością człowieka to doskonałość tego czynnika, który ożywia go i uzdalnia do rozumowego myślenia i działania. Doskonałością wtórną natomiast jest cel, którym jest już to samo działanie już to coś co osiąga się przez to działanie. Doskonałość podstawowa jest przyczyną i źródłem doskonałości wtórnej, a wtórna jest celem doskonałości podstawowej. Doskonała szczęśliwość jest niemożliwa na tej ziemi, gdyż życie na naszej planecie obfituje w cierpienia i kończy się śmiencią. Wiara religijna poucza o możliwości osiągnięcia pełnej doskonałości i szczęśliwości polegającej na „najdoskonalszym działaniu najdoskonalszego uzdolnienia ludzkiego w stosunku do najdoskonalszego przedmiotu", którym jest Bóg ${ }^{50}$. Natomiast na tej ziemi jest możliwe osiągnięcie niedoskonałej szczęśliwości i doskonałości, polegającej na kulturze moralnej w znaczeniu zespołu sprawności $\mathrm{w}$ postępowaniu zgodnym $\mathrm{z}$ ostatecznym celem życia ludzkiego. Zespół takich sprawności, wyrażający się w wytrwałym i starannym dążeniu

48 Summa Theologica, I, q. 73, a. 1.

$49 \mathrm{Ks}$. H. Juros, Subiektywna definicja dobra, w: Rocznilki Filozoficzne, 22 (1974), z. 2, 57.

50 Suma Teologiczna I-II, q. 3, a. 5. W przekł. Bednarskiego, t. 9, 70.

12 - Analecta Cracoviensia 
do wzniosłych celów zgodnie z właściwym celem życia ludzkiego, nazywamy charakterem moralnym. W miarę jak człowiek zdobywa go, usprawniając się $w$ dobrym moralnie postępowaniu, dokonuje niejako samourzeczywistnienia, stając się coraz bardziej rozumnym, a więc coraz bardziej człowiekiem.

Jak widać z powyżej przytoczonych tekstów, św. Tomasz ujmuje szczęśliwość i doskonałość nie statycznie, jako ustanie wszelkiego działania, ale dynamicznie jako działanie, urzeczywistniające pełną możliwości ludzkich $\mathrm{w}$ doskonaleniu życia. Człowiek zmierza do urzeczywistnienia swych uzdolnień tak samorzutnie jak roślina dążąca do światła słonecznego, ale pełnia rozwoju tych uzdolnień jest czymś swoistym dla każdego człowieka, gdyż nie ma jednakowej miary doskonałości dla wszystkich ludzi.

Jak zaznacza św. Tomasz, ostatecznym celem życia ludzkiego nie może być samo tylko zachowanie tego życia „,bo jest rzeczą niemożliwą, by ostateczny cel tej rzeczy, która służy do osiągnięcia innego celu, polegał na zachowaniu jej istnienia. Podobnie sternik nie zmierza do zachowania swego okrętu jako do celu ostatecznego, gdyż okręt służy do osiągnięcia ínnego celu, a mianowicie do żeglugi. Otóż podobnie jak sternikowi powierza się okręt, by nim kierował, tak też człowiek został powierzony swej woli i swemu rozumowi... Nie ulega zaś wątpliwości, że człowiek jest skierowany do jakiegoś celu: wszak nie jest dobrem najwyższym. A więc jest rzeczą niemożliwą, by ostateczny cel rozumu i woli pólegał na zachowaniu życia ludzkiego" s1.

Wbrew temu poglądowi św. Tomasza, marksiści w teorii uznają człowieka właśnie za najwyższe dobro, ale zazwyczaj nie określają o jakiego człowieka chodzi: czy o każdego, a jeśli tak to także bandyta, złodziej, chuligan byłby najwyższym dobrem społeczeństwa, należałoby go cenić, nie skazywać go na śmierć i nie narażać go na nią; a jeśli nie każdy człowiek, to kto ma osądzać, kogo należy uważać za najwyższe dobro i na jakiej podstawie, według jakiej miary, podług jakiego ideału? A jeśliby istniała taka miara czy taki ideał, wówczas najwyższym dobrem nie byłby człowiek, ale urzeczywistnienie tej miary czy osiągnięcie owego ideału.

Sw. Tomasz odróżnia w celu ostatecznym przedmiot, który ma uszczęśliwić człowieka, oraz osiągnięcie tego celu i posiadanie go jako szczęścia, zaznaczając, że: „Szczęście jest dobrem doskonałym, całkowicie zaspokajającym pożądanie (a tym samym wszystkie potrzeby ludzkie). Nie byłoby bowiem celem ostatecznym, jeśliby po jego osiągnięciu zostało jeszcze coś do pożądania. Przedmiotem zaś woli, czyli pożą-

51 Tamże, I-II, q. 2, a. 5, s. 49 , 
dania ludzkiego, jest dobro powszechne, podobnie jak przedmiotem umysłu jest prawda powszechna. Jasne więc, że nic nie może zaspokoić woli czlowieka poza dobrem powszechnym" ${ }^{52}$. Ale co jest tym dobrem powszechnym? Dobro ogółu społeczeństwa? Ale dobro ogółu społeczeństwa jest dobrem ludzi, którzy je tworzą.

\section{TRESĆ PRAWA PRZYRODZONEGO}

W poglądach na treść prawa przyrodzonego można odróżnić trzy poglądy: jedni uznają je za formę umysłu ludzkiego bez jakiejkolwiek treści, inni przyjmują prawo naturalne o niezmiennej treści, a jeszcze inni uznają prawo naturalne o zmiennéj treści.

Rzecznikiem pierwszego poglądu był E. Kant, według którego prawo moralne jest tylko aprioryczną formą rozumu i ma charakter czysto formalny: „Jeżeli rozumna istota ma pojmować swoje maksymy jako praktyczne ogólne prawa, to może je pomyśleć tylko jako takie zasady, które zawierają motyw woli nie ze względu na materię, lecz tylko ze względu na formę" ${ }^{53}$. W ślad za Kantem, wielu przedstawicieli filozofii chrześcijańskich, idących za deontologicznym nurtem etyki, przypisują także prawu naturalnemu charakter wyłącznie formalny, pozbawiony wszelkiej treści, wszelkich praktycznych wytycznych, norm czy przepisów ${ }^{54}$.

$\mathrm{Za}$ zmienną treścią prawa natury opowiadają się niektórzy neokantyści, a także J. Sauter, R. Stammler, L. Petrażycki, G. Radbrach, G. Del Vecchio ${ }^{55}$, przyrównując to praw̌o do niezmiennych reguł logiczno-matematycznych, za które można podstawić najrozmaitsze zdania. Tak samo, według nich; prawo naturalne to reguła, której forma jest niezmienna, ale treść jest ważna jedynie dla określonego państwa w określonych warunkach. Forma ta jest idealnym pierwowzorem i wyznacznikiem kierunku rozwoju prawodawstwa, nie może więc być pusta, ale musi być wypełniona jakąś treścią, nadaną jej przez konkretne warunki życia, ale treści tej niepodobna wysnuć z samego prawa. Gdyby jednak tak było, jak słusznie zauważył J. Messner ${ }^{56}$ prawo naturalne byłoby samo przez się systemem pustych formuł, które każda grupa zwycięzców mogłaby napełniać dowolną treścią.

Za niezmienną treścią prawa naturalnego oświadczają się ci, którzy wyprowadzają je $\mathrm{z}$ natury człowieka, pojętej w znaczeniu niezmiennej istoty, a nie $\mathrm{w}$ znaczeniu dynamicznej zasady działania swoistego dla

52 Tamże, I-II, q. 2, a. 8, s. 57 .

53 Kant, Krytyka praktycznego rozumu, 35.

${ }^{5}$ Np. K. Rahner, Die Antwort der Religionen, München 1965, 20.

55 Szyszkowska, dz. cyt. 86-116.

56 J. Messner, Sind die Naturrechtsprinzipien Leerformen? Moral zwischen Anspruch und Verantwortung. Festschrift für W. Schölingen, Düsseldorf 1964, 318-336. 
ludzi, a więc zmiennej, jak przyjmuje św. Tomasz z Akwinu, mówiąc: „natura człowieka jest zmienna. Dlatego co jest przyrodzone człowiekowi niekiedy zawodzi" ${ }^{57}$.

W empirycznym ujęciu prıwa przyrodzonego jako prawidłowości w uporządkowaniu psychofizycznych składników, skłonności oraz uzdolnień, skłaniających ludzi do zaspokajania właściwych im potrzeb życia osobowego i społecznego, stwierdziliśmy, że tak jak przez analizę budowy i funkcjonowania jakiegoś mechanizmu, np. zegarka, można wysnuć normy, jak należy obchodzić się z nim, by spełnił swe zadanie, tak tė̇ z analizy i struktury osobowości ludzkiej można wysnuć: a) jak należy postępować, by ludzie spełnili swe zadanie życiowe, zaspokajając swe potrzeby $\mathrm{w}$ sposób rozumny, b) uzasadnienie tych norm $\mathrm{w}$ postaci ocen, wskazujących dlaczego tak a nie inaczej należy postąpić w takich a takich okolicznościach. Te właśnie normy postępowania oraz oceny, oparte na wartościowaniu i służące do uzasadnienia norm, stanowią treść prawa przyrodzonego $\mathrm{w}$ tym znaczeniu, że dadzą się wysnuć ze struktury i funkcjonowania osobowości ludzkiej. Ale czy takie wyprowadzenie norm $\mathrm{i}$ ocen jest $\mathrm{w}$ ogóle możliwe? Czy z faktów, stwierdzających jak było lub jest, można wnioskować, jak powinno być? Czy w ogóle oceny i normy dadzą się wyprowadzać logicznie ze zdań, opisujących fakty, rzeczy, cechy, stosunki czy zdarzenia? Jak wiadomo, zwolennicy emotywizmu etycznego, R. Carnap, A. J. Ayer, B. Russell, Ch. J. Stewenson i inni, nie uznają ocen i norm za zdania w znaczeniu logicznym, które by można uzasadniać czy wyprowadzać ze zdań sprawozdawczych, gdyż „są niczym innym więcej, niż rozkazem w błędnej gramatycznie formie", jak się wyraził $R$. Carnap ${ }^{58}$. Oceny i normy, podług emotywistów, wyrażają tylko jednostkowe lub zbiorowe postawy uczuciowe lub wolitywne, a nie zgodność lub niezgodność z rzeczywistością. Mogą więc być najwyżej zalecane, ale nie mogą być dowodzone, czy wyprowadzane $\mathrm{z}$ innych zdań, nie mogą być ani prawdziwe, ani fałszywe. Podobnie zwolennicy deontologicznego pojmowania prawa moralnego, jak H. A. Prichard, G. A. Moore, E. F. Carrit, C. D. Broad, W. D. Ross, uznając wartość moralną za cechę niezależną od rzeczywistości zmysłowej lub metafizycznej, osądzają traktowanie zdań opisowych oraz oceniających jako przesłanek norm za przykład szeroko rozpowszechnionego błędu naturalistycznego, gdyż powinność etyczna, według nich, nie potrzebuje żadnego uzasadnienia, bo jest poznawalna intuicyjnie ${ }^{59}$. Wspól-

57 Suma Teologiczna, II-II, q. 57, a. 2, ad 1. W przekł. Bednarskiego, t. 18, London 1967, s. 20. Tamże kom. 267-274.

58 R. Carnap, Philosophy and Logical Syntax, s. 34, cyt. za Z Szawarski, Trzy stadia emotywistycznej teorii sporu etycznego, w: Etyka I, Warszawa 1966, 268.

${ }^{59}$ S. Soldenhof, Stuszność $i$ obowiq̨zek $w$ systemie etyki W. D. Rossa, w: Etyka I, Warszawa 1966, 221-264. 
ną wiarą emotywistów i deontologistów jest antynaturalizm, tj. przekonanie o nieprzekładalności ocen i norm etycznych na język empiryczno-opisowy ${ }^{60}$.

Przekonanie to nie jest uzasadnione, gdyż po 1. nie ma ostrej granicy między zdaniami opisowymi a wartościującymi, wiele zdań stwierdzających np. użyteczność jakiegoś narzędzia, ma charakter zarówno opisowy jak i oceníający, po 2. gdy ktoś wypowiada ocenę, że np. kłamstwo jest złe, nie zawsze wyraża swą postawę uczuciową w stosunku do niego, czy np. podoba się mu kłamstwo czy nie, i po 3. wiele wyrazów oceniających można przełożyć na wyrazy opisowe, a zdania wartościujące i normatywne na zdania spostrzeżeniowe, zwłaszcza w teleologicznym, czyli celowościowym ujęciu etyki, uznającym za moralnie dobre to, co jest zgodne $\mathrm{z}$ ostatecznym celem życia ludzkiego, a za złe to, co sprzeciwia się temu celowi; konkretniej w ujęciu empirycznym moralnie dobrym jest postępowanie, które rozumnie zaspokaja potrzeby życia ludzkiego, a moralnie złym jest takie zachowanie, które uniemożliwia rozumne zaspokojenie potrzeb tegoż życia.

Empirycznie można ustalić, jakie są rzeczywiste potrzeby życia ludzkiego, oczywiście nie tyle metodą ankiet ile raczej metodą dokładnych obserwacji, badając co jest konieczne lub użyteczne do zachowania i rozwoju życia ludzkiego osobowego i społecznego. Czy empirycznie można poznać wszystkie potrzeby tego życia? Jest faktem, empirycznie stwierdzalnym, że wiele ludzi ma wiele potrzeb, których nie odczuwa, np. potrzebę panowania nad swymi popędami, niesienia pomocy tym, którzy jej potrzebują. Często też odczuwają potrzebę niektórych rzeczy dopiero wtedy gdy je stracą, np. ,zdrowie, ile je cenić trzeba ten tylko się dowie, kto je stracił" jak mówi wieszcz narodowy. Wiele potrzeb ludzkich dopiero nauka wykrywa, choć niejednokrotnie sama je stwarza, np. potrzebę posiadania auta, telewizora, lodówki, światła elektrycznego itp. Nieraz takie nauki empiryczne, jak psychologia czy socjologia, stwierdzają istnienie pewnych potrzeb bardzo ważnych dla życia ludzkiego w sposób ogólnikowy, bez wnikania w konkretne szczegóły, np. potrzebę kultury moralnej, dążenia do ostatecznego celu życia ludzkiego, gdyż nie potrafią wskazać, na czym ów cel polega. Niemniej tego rodzaju nauki stwierdzają, że ludzie nieraz odczuwają potrzebę wiary religijnej w Objawienie Boże, które wskazałoby, na czym konkretnie polega ów cel, nadający sens życiu ludzkiemu, by nie było gonitwą za nieosiągalnym na tej ziemi szczęściem i złudą i by nie było bezsensowne.

Wiedza empiryczna jest zdolna nie tylko do wskazania niektórych potrzeb życia osobowego i społecznego, ale także do podania rozumnego

60 R. M. Hare, Broad's Aproach to Moral Philosophy, New York 1959, 471. 
sposobu ich zaspokojenia tak, by było użyteczne dla zdrowia fizycznego, psychicznego i moralnego poszczególnych osób oraz społeczności, w której żyją. Zresztą rozumny sposób zaspokajania potrzeb ludzkich jest również potrzebą każdego człowieka, jak stwierdza codzienne doświadczenie. Nierozumne bowiem zaspokojenie potrzeb często powoduje większą szkodę, niż ich niezaspokojenie.

Ale czyja wiedza i na jakiej podstawie ma rozstrzygać, jakie są potrzeby poszczególnych ludzi oraz społeczeństw i jaki jest rozumny sposób zaspokajania tych potrzeb? Naukowcy?, politycy?, prawnicy?, lekarze?, każdy człowiek w stosunku do siebie samego? Należy odróżnić potrzeby rzeczywiste odczuwane i nieodczuwane, osobiste oraz społeczne. Gdy chodzi o potrzeby osobiste odczuwane przez poszczególne osoby, mające używanie rozumu, bezpośrednimi sędziami swych potrzeb są te właśnie osoby, które odczuwają owe potrzeby. Tylko ten, kto odczuwa pragnienie, może stwierdzić bezpośrednio czy je odczuwa, czy należy zaspokoić je, czy też nie należy ze względu na różne okoliczności, warunkujące to zaspokojenie. Nieraz jednak zdarza się, że niektórzy ludzie odczuwają potrzebę tych rzeczy, które są im niepotrzebne, a nawet szkodliwe, np. potrzebę picia napojów alkoholowych, palenia papierosów, przedmałżeńskich stosunków seksualnych itd., przy czym niekiedy zdają sobie sprawę ze szkodliwości lub bezużyteczności tej rzeczy, której potrzebę odczuwają, a niekiedy nie zdają sobie $z$ tego sprawy. W tym ostatnim wypadku zadaniem naukowców, polityków, społeczników, duszpasterzy, dziennikarzy itp. jest uświadomienie owych ludzi, zwłaszcza gdy zaspokajanie tego rodzaju potrzeb jest szkodliwe dla innych osób, np. dla dzieci. Czasami nnwet przedstawiciele władzy społecznej winni zakazać zaspokajania owych potrzeb i zakaz wzmocnić zagrożeniem stosownej kary. Tak samo ci wszyscy, którzy są odpowiedzialni za rozwój życia społecznego, a więc naukowcy, politycy, duszpasterze, a zwłaszcza wychowawcy powinni wzbudzić zapotrzebowanie rzeczy niezbędnych dla rozwoju kultury w ludziach, którzy nie odczuwają potrzeby tego rodzaju rzeczy, np. odnośnie do higieny, przestrzegania prawideł ruchu ulicznego, płacenia podatków, pogłębiania fachowej wiedzy itd. Potrzeba tego rodzaju uświadamiania ludzi jest faktem empirycznym, nie ulegającym wątpliwości.

Niekiedy jednak w sprawach bardzo ważnych nawet naukowcy i specjaliści w określonym typie potrzeb mają wątpliwości, czy uznać daną potrzebę za rzeczywistą czy tylko za pozorną, a jej zaspokojenie za użyteczne lub konieczne, czy też za bezużyteczne lub nawet szkodliwe dla życia osobowego, względnie społecznego. Nieraz ich poglądy w tych sprawach są sprzeczne i jedynie długotrwałe i staranne badanie wszystkich okoliczności może z czasem doprowadzić do usunięcia wątpli- 
wości i do odpowiedniego zadziałania. Gorzej jest wtedy, gdy nie ma czasu na badanie, a trzeba natychmiast powziąć decyzję, przynajmniej taką, by jej urzeczywistnienie było jak najmniej szkodliwe.

Zachodzi jednak pytanie, czy zaspokajanie potrzeb ma wartość moralną i czy zdatność określonego rodzaju postępowania do ich zaspokojenia może być miarą i sprawdzianem godziwości lub niegodziwości czynów ludzkich. Oczywiście, chodzi o dobrowolne zaspokajanie tych potrzeb, czyli dokonane na podstawie osobistej zgody, gdyż postępo'wanie niedobrowolne nie może być ani dobre ani złe pod 'w'zględem moralnym, czyli nie posiada żadnej wartości etycznej

Odpowiedź zwolenników deontologicznego ujmowania prawa moralnego jest przecząca, gdyż oni uznają za moralne jedynie takie postępowanie, które wypływa $\mathrm{z}$ poszanowania dla prawa, czy z poczucia powinności; natomiast działanie podjęte dla jakiegokolwiek innego celu uważają za amoralne lub tylko za legalne. Natomiast zwolennicy celowościowego ujęcia etyki, a w szczególności arystotelicy, stoicy i tomiści, odróżniają dobrowolne i niedobrowolne zaspokajanie potrzeb czy jakiekolwiek inne postępowanle (w praktyce każde postępowanie świadomie lub nieświadomie zmierza do zaspokojenia jakiejś rzeczywistej lub pozornej potrzeby, bo wypływa z jakiejś skłonności). Postępowanie, które ani wprost ani niewprost, ani bezpośrednio ani pośrednio nie jest dobrowolne, nie może być ani dobre ani złe pod względem moralnym, czyli nie posiada żadnej wartości etycznej, podobnie jak postępowanie zwierząt lub dzieci nie posiadających jeszcze używania rozumu. Natomiast wszelkie dobrowolne postępowanie jest w praktyce zawsze albo dobre albo złe pod względem moralnym, bo albo jestr.rozumne pod każdym względem, albo jest nierozumne przynajmniej ze względu na jedną okoliczność moralną, gdyż moralnie dobrym jest tylko postępowanie pod każdym względem rozumne, czyli zgodne $\mathrm{z}$ wymaganiami ,prawego" rozumu, czyli należycie skierowanego do właściwego celu życia ludzkiego ${ }^{61}$. Jeśli więc dobrowolne zaspokajanie potrzeb życia ludzkiego jest pod każdym względem rozumne, wówczas ma dodatnią wartość moralną, jeśli natomiast choćby pod jednym względem etycznej natury jest nierozumne, np. ze względu na zły zamiar, egoistyczną intencję, sposób wykonania, niewłaściwe pod względem moralnym środki, niewłaściwy czas, nieodpowiednie miejsce, wówczas jest moralnie złe, gdyż wówczas jest nierozumne, np. gdyby ktoś chciał zaspokoić potrzebę napoju piciem nadmiernej ilości alkoholu; ale kiedy ta ilość jest nadmierna i tym samym grzeszna, moralista może określić nie na podstawie założeń me-

${ }^{61}$ Zagadnienie to omawia szczegółowo św. Tomasz w: Suma Teologiczna I-II, q. 18. a. $8-9$. W przekł. Bednarskiego, t. 9 , s. $306-312$. 
tafizycznych, ale jedynie w oparciu o dane medycyny, psychologii i socjologii.

Oczywiście z empirycznego punktu widzenia nie można twierdzić, że tylko na podstawie danych empiry'cznych można określić, kiedy zaspokojenie potrzeb życia ludzkiego jest ¡pod każdym względem rozumne i tym samym moralnie dobre, a, kiedy jest nierozumne i tym samym moralnie złe, gdyż nauki empiryczne $z$ zasady wystrzegają się wielkich kwantyfikatorów, takich jak ,tylko”, „każdy”, ,nikt”, „wszędzie”, „nigdzie”, ,zawsze”, „nigdy”. Ponadto wiedza empiryczna nie ma sposobu, by stwierdzić niemożność istnienia innych sprawdzianów wartości etycznej, podobnie jak nauki teologiczne oraz filozoficzne posługując się metodą właściwą dla tych nauk, nie mogą wykluczyć danych empirycznych jako podstawy oceny i normowania wartości moralnej spostrzegalnych czynności, skoro nie mogą zaprzeczyć istnienia licznych potrzeb życia ludzkiego, spostrzegalnych empirycznie, ani nie mogą zaprzeczyć faktu, że niekiedy tylko doświadczenie empiryczne może wskazać rozumny sposób ich zaspokojenia. W praktyce empiryczne sprawdziany rozumności postępowania ludzkiego nie budzą tyle sprzeciwów, co np. sprawdziany wysuwane przeź filozofów, a zarazem dadzą się zastosować w przeróżnych dziedzinach życia osobowego i społecznego ze względu na bardzo szeroki zakres potrzeb, których zaspokojenie wymaga oparcia się na danych socjologicznych, psychologicznych, biologicznych i historycznych.

Jednym z najbardziej podstawowych warunków rozumnego zaspokajania potrzeb życia ludzkiego jest uwzględnianie ich hierarchii, by potrzeby pcdrzędne podporządkować nadrzędnym w zależności od tego, które są ważniejsze dla zachowania życia ludzkiego i jego doskonalenia. Otóż dane empiryczne w dużej mierze umożliwiają takie podporządkowanie, wskazując, jakie rzeczy są niezbędne do życia ludzkiego w ogóle, a jakie służą do jego udoskonalenia. Ale dane empiryczne nie są zdolne do ustalenia bezwzględnie najwyższej potrzeby, niedostępnej ani dla bezpośrednich ani pośrednich spostrzeżeń empirycznych, bo na podstawie tych danych nie można orzec czy zaspokojenie bezwzględnie wszystkich potrzeb życia ludzkiego, a więc zupełna doskonałość i szczęśliwość, jest możliwa po śmierci. Ale stwierdzając możliwość częściowej doskonałości, polegającej na kulturze moralnej, będącej częścią integralnej doskonałości, dane empiryczne mogą dostarczyć wiele cennych wskazówek, jak tę doskonałość moralną zdobywać.

Empiryczne stwierdzenie, że określony typ postępowania jest konieczny lub niekonieczny, przydatny lub szkodliwy dla życia ludzkiego osobowego i społecznego, stanowi pewnego rodzaju wartościowanie, a zdanie, które to wartościowanie wyraża, jest oceną. Czy jest oceną mo- 
ralną? Znaczenie postępowania, jego charakter, pobudki, następstwa oraz okoliczności można rozpoznawać jako wartości dodatnie lub ujemne dla pojedynczej osoby lub dla społeczeństwa czy dla całej ludzkości już to wyłącznie biorąc pod uwagę pewne względnlie ostateczne cele życia ludzkiego i uwikłane 'w nich wartoścr', już to ze względu na to co w ogóle nadaje sens istnieniu poszczególnych ludzi i całej ludzkości, czyli ze względu na stosunek owego postępowania do bezwzględnie ostatecznego celu życia lùdzkiego, do możliwie pełnej jego ,doskonałości. Tylko w tym drugim znaczeniu ocenę nazywamy moralną, czy raczej etyczną, jako opartą na wartościowaniu postępowania ludzkiego podług jego stosunku do bezwzględnie ostatecznego celu, możliwego do przynajmniej częściowego urzeczywistnienia przez zespół uporządkowanych działań, tworzących lub zdobywających różne wartości etyczne, z których wiele może być przєđmiotem pośredniego spostrzeżenia empirycznego.

Tak więc $\mathrm{w}$ bardzo wielu ocenach etycznych są uwikłane oceny empiryczne, stwierdzające zdatność lub niezdatność, użyteczność lub szkodliwość danego typu postępowania do zaspokojenia potrzeb ludzkich, będącego już to środkiem, już to warunkiem, już to składnikiem zaspokojenia 'naczelnej i nadrzędnej potrzeby, jaką jest potrzeba doskonalenia życia osclbowego i społecznego. Tak np. zaspokojenie wielu potrzeb biologicznych, takich jak oddychanie, odżywianie, sen, jest niezbędnym warunkiem życia oraz możliwości zaspokojenia wyższych potrzeb, których przedmiotem są składniki doskonałości życia ludzkiego, takie jak sprawności umysłowe oraz moralne, które nie są już środkami do zdobycia doskonałości, ale jej składnikami, a tym samym są wartościami same w sobie.

Wiedza empiryczna nie wskazuje bezwzględnie ostatecznego celu jako miary i sprawdzianu wartości moralnej postępowania, nie podaje naczelnej zasady życia ludzkiego, nie głosi co jest moralnie dobre lub złe (najwyżej przytacza poglądy o tym, co różni ludzie nazywają dobrem a co złem), ale stwierdza, że ludzie pożądają w miarę możliwości zaspokojenia wszy'stkich swych potrzeb i dążą do tego czasem rozumnie, gdy czynią to, co prowadzi do zaspokojenia rzeczywistych potrzeb, a czasem nierozumnie, gdy ich zachowanie uniemożliwia zaspokojenie rzeczywistych potrzeb, tzn. takich, których zaspokojenie jest niezbędne do zachowania lub udoskonalenia życia. Oczywiście przedstawiciele wiedzy empirycznej nie oburzają się, gdy teologowie lub filozofowie nazwą fakt empirycznie stwierdzalny, że takie a takie postępowanie zaspokaja potrzeby życia ludzkiego w sposób rozumny - postępowaniem moralnie dobrym, jako adpowiadającym osobowości człowieka, a postępowanie uniemożliwiające takie postępowanie - moralnie złym; innymi słowy, gdy etycy ujmą zdanie empiryczne jako ocenę moralną, albo gdy uogól- 
niając empirycznie stwierdzalną potrzebę doșkonalenia życia, a więc ezynienia go coraz lepszym, nazwą stan dynamicznego zaspokojenia wszystkich rzeczywistych potrzeb w sposób rozumny - doskonałością, uznając ją za najwyższy ideał, do którego należy dążyć i według którego należy oceniać wartość moralną postępowania ludzkiego. W ten sposób jedna i ta sama wypowiedź może mieć sens działania empirycznego i oceny etycznej, zależnie od sposobu uzasadnienia: na podstawie zdań spostrzeżeniowych, czy też na podstawie metafizycznych lub teologłcznych naczelnych założeń.

$\mathrm{Na}$ empiryczne podstawy wielu ocen etycznych niejednokrotnie wskazywał św. Tomasz z Akwinu, zwłaszcza w odniesieniu do potrzeb oraz do skłonności przyrodzonych $\mathrm{ku}$ ith zaspokojeniu. Rozważając zagadnilenie: „Czy potrzeby obecnego życia należy uznać za normę umiarkowania” nie zawahał się napisać: „Dobroć cnoty moralnej polega głównie na rozumnym porządku, gdyż jest zgodnością postępowania z rozumem ...Ten zaś porządek polega przede wszystkim na skierowaniu do (właściłwego) celu ...bo dobro ze swej istoty jest celem, a cel jest normą tych rzeczy, które są dla celu. Otóż celem przyjemności, doznawanych przez ludzi, jest zaspokojenie jakiejś potrzeby życiowej. Dlatego regułą umiarkowania w przyjemnościach są potrzeby życia by używać ich tyle, ile tego wymaga potrzeba życia" ${ }^{62}$. Zaraz potem czyni Akwinata następujące bardzo ważne rozróżnienie: ,potrzeby życiowe można pojmować dwojako: albo jako konieczność czegoś bez czego w ogóle nie można istnieć, w ten sposób np. pokarm jest konieczny dla zwierząt, - albo też potrzebę czegoś bez czego nie można istnieć w odpowiedni sposób. Otóż umiarkowanie obejmuje nie tylko pierwszy, ale także drugi rodzaj potrzeby. Lecz przyjemności nie konieczne do życia są dwojakiego rodzaju: jedne są szkodliwe dla zdrowia i dobrego stanu, otóż takich przyjemności człowiek umiarkowany nie używa, bo to byłoby grzechem przeciwko umiarkowaniu; inne zaś przyjemności nie są szkodliwe i tych człowiek umiarkowany używa z umilarem stosownie do miejsca, czasu oraz właściwego stosunku do osób, z któryłmi współżyje" ${ }^{63}$. Pisząc zaś o małoduszności, św. Tomasz nie zawahał się stwierdzić: „Cokolwiek sprzeciwia się przyrodzonej skłonności jest grzechem, gdyż jest sprzeczne z prawem naturalnym. W każdym zaś człowieku istnieje skłonność ku temu co jest współmierne do jego możliwości" ${ }^{64}$. Jasne więc, że według Akwinaty, skłonności przyrodzone, jako przejawy prawa przyrodzonego, zmierzające ku zaspokojeniu potrzeb życia ludzkiego, są podstawą wielu ocen etycznych oraz norm moralnych.

${ }^{62}$ Suma Teologiczna, II-II, q. 141, a. 6. W przekł. Bednarskiego, t. 22, s. 1921.

63 Tamże.

64 Tamże. q. 133, a. 1. 
Jeśliby można było rozumieć ,impulșywne działania”, o których mówi B. Russell, w znaczeniu tomaszowych skłonności przyrodzonych, można by uznać za słuszne jego twierdzenie, że ich tamowanie lub stłumienie kryje $\mathrm{w}$ sobie poważne niebezpieczeństwo $\mathrm{w}$ postaci utraty sił życiowych, znudzenia, braku zainteresowania dla bieżących spraw, złośliwości, zazdrości oraz uniemożliwienia pełnego rozwoju osobowości, jak to jeszcze bardziej podkreśla psychoanaliza ${ }^{65}$. Człowiek, który stale zwraca swe siły na zwalczanie przyrodzonych skłonności, nie może zachować energii koniecznej do tworzenia tych dzieł czy sprawności, dla których zdobywał się na ciągłe wyrzeczenia i które prędzej lub później zobojętnieją mu właśnie na skutek tłumienia tych przyrodzonych skłonności, zamiast skierowania ich ku tworzeniu tego co piękne, szlachetne, radosne i twórcze. W wyniku ustawicznego tłumienia przyrodzonych skłonności człowiek nie wykształci w sobie silnej i zdrowej osobowości i nie będzie zdolny do zajęcia twórczej postawy wobec życia: Winę za marnowanie tych twórczych skłonności ponosi często wychowanie, oparte na nieuświadomionym zazwyczaj podejściu manichejskim do ciała ludzkiego, nastawionym wyłącznie negatywnie na unikanie grzechu, a nie na różnorodną twórczość przez zdobywanie sprawności umysłowych i moralnych, którym św. Tomasz poświęcił większą część swej Sumy, traktując o wadach i grzechach jakby na marginesie swych rozpraw o sprawnościach, których zadaniem jeist właśnie to, co współcześni nazywają „samourzeczywistnianiem" człowieka, czyli urzeczywistnianiem jego możliwości doskonalenia siebie i życia społecznego oraz przyrody tak, by nieskrępowany rozwój jego osobowości był coraz bardziej twórczy, coraz mniej związany z jego egocentryzmem, a coraz ściślej spleciony z dobrem ogółu całej ludzkości. To rozwijanie przyrodzonych uzdolnień i skłonności w nauce św. Tomasza spełnia rolę zwornika, spajającego rozmaite wątki jego etyki, a szczególnie tego co nazwał prawem naturalnym.

Rozróżnienie św. Tomasza takich potrzeb, których zaspokojenie jest niezbędne do życia $w$ ogóle, i takich, których zaspokojenie jest konieczne do odpowiedniego życia ludzkiego pozwala uznać oceny etyczne za przekładalne na zdania, zdające sprawę $\mathrm{z}$ pewnych empirycznie uchwytnych cech wartościowanego postępowania, przysługujących mu przedmiotowo, tzn. niezależnie od tego czy ktoś je pochwala lub gani, czy komuś ono podoba się lub nie. Czy taki pogląd jest obiektywizmem naturalistycznym? Jest obiektywizmem, bo oceny etyczne opiera na przedmiotowym stosunku postępowania do zaspokojenia potrzeb życia, ale nie jest obiektywizmem naturalistycznym lecz prefekcjonistycz188.

${ }^{65} \mathrm{Cz}$. Porębski, Perfekcjonizm Bertranda Russella, w: Etyka, 13 (1974), 187- 
nym, bo nie twierdzi, że zdatność jakiegoś postępowania do zaspokojenia jakiejkolwiek potrzeby jest moralnie dobra, ale że rozumne zaspokojenie rzeczywistych potrzeb jest etycznie dobre jedynie wtedy, gdy pod każdym względem jest rozumne i tym samym zgodne $\mathrm{z}$ naczelnym celem życia ludzkiego. Z tego np., że zamordowanie uczciwego przywódcy opozycji rządu w jakimś kraju zaspokoiło potrzebę ułatwienia zjednoczenia politycznego, bynajmniej nie wynika, że byłby to czyn moralnie dobry, skıro sam w sobie i pod wieloma innymi względami jest nierozumny i tym samym moralnie zły, gdyż prowadzi nie ku doskonaleniu życia, lecz wręcz przeciwnie ku jego niszczeniu i upodleniu. Nie dlatego też postępowanie jest dobre, że rozumnie zaspokaja potrzeby życia ale dlatego zaspokaja te potrzeby, bo jest dobre.

Dynamiczne ujęcie prawa przyrodzonego u św. Tomasza, a zwłaszcza jego zasada, że „podług porządku skłonności przyrodzonych są uporządkowane przykazania prawa przyrodzonego" ${ }^{66}$, zaleca pojmowanie tychże skłonności nie jako zbioru gotowych norm postępowania moralnego, ale jako wyznacznika kierunku, w którym mają zmierzać wysiłki w formułowaniu wytycznych prawa przyrodzonego. Badając ukierunkowanie przyrodzonych skłonności ku zaspokojaniu potrzeb życia ludzkiego i stwierdzając, co jest konieczne lub przydatne, a co szkodliwe lub nieprzydatne - na podstawie danych empirycznych można wyprowadzić pewne oceny moralne.

\section{EMPIRYCZNE UZASADNIANIE WYTYCZNYCH PRAWA PRZYRODZONEGO}

Od dawna etycy spierają się o to, czy normy postępowania moralnego dadzą się wyprowadzić z ocen i zdań nienormatywnych, a więc np. opisowych lub stwierdzających istnienie pewnych cech, stosunków, zdarzeń. Wielu twierdzi, że norm etycznych w ogóle nie da się uzasadnić, gdyż będąc wyrazami postaw uczuciowych jednostek lub grup społecznych, nie są zdaniami w sensie logicznym, nie są ani prawdziwe ani fałszywe, nie można więc ich uzasadnić ani obalić, można je tylko albı zalecać albo odrzucać. Tak twierdzą zwolennicy emotywizmu etycznego.

Natomiast intuicjoniści, oraz niektórzy zwolennicy deontologizmu etycznego, sądzą, że normy postępowania moralnego nie potrzebują żadnego uzasadniania, gdyż są oczywiste i stanowią przedmiot intuicji umysłowej lub zmysłu moralnego. Moc wiążącą tego rodzaju norm poznajemy bezpośrednio przez intuicję. Wreszcie zwolennicy teleologizmu etycznego czyli celowościowego ujmowania zagadnień moralnych, sądzą,

66 Summa Theologica, I-II, q. 94, a. 2. 
że uzasadnianie norm postępowania moralnego jest nie tylko możliwe, ale wprost konieczne. Ale różnie pojmują to uzasadnianie.

Logika odróżnia dwa rodzaje rozumowań uzasadniających w znaczeniu przechodzenia od jednych sądów do drugich: dedukcyjne, w którym dobiera się następstwa do racji, uprzednio uznanej za prawdziwą (wnioskowanie) lub dobieramy następstwa, skądinąd uznane za prawdziwe do racji, będącej zdaniem, które chcemy sprawdzić (sprawdzanie) — oraz redukcyjne, w którym dobiera się rację do następstwa skądinąd uznanego za prawdziwe (tłumaczenie), względnie dobiera się rację, skądinąd uznaną za prawdziwą do następstwa (dowodzenie) ${ }^{67}$.

Otóż niektórzy, pewnie w przeświadczeniu, że norm moralnych nie da się wnioskować ze zdań empirycznych, a zwłaszcza antropologicznych, zalecają szeroko pojętą redukcję. Tak np. ks. prof. Tad. Styczeń pisze ${ }^{68}$ : „W szczególności... należałoby 'rozpatrzyć... ewentualność wiązania tez obu dyscyplin (etyki i antropologii) nie na zasadzie dedukcji tez etyki z tez o naturze ludzkiej lecz na zasadzie redukcji tez etyki do tez o naturze ludzkiej".

Ale nie wydaje się, by wymaganie poszerzenia pojęcia uzasadnienia redukcyjnego znalazło uznanie u logików i było konieczne, jeśli na podstawie danych empirycznych można sformułować oceny o konieczności pewnych typów postępowania, a w oparciu o te oceny wysnuć normy etyczne o tym co należy czynić i czego nie należy czynić, by postępowanie człowieka $\mathrm{w}$ danych okolicznościach było naprawdę rozumne pod każdym względem i tym samym moralnie dobre. To uporządkowanie, jak widzieliśmy, jest faktem empirycznie stwìerdzonym. Ale czy z faktów, a. raczej ze zdań opisujących je, dadzą się wyprowadzić normy postępowania moralnego? Czy z tego, że coś jest tak lub owak, można wnioskować, że powinno być tak lub inaczej? Innymi słowy, czy z bytu można wysnuć powinność? Liczni myśliciele, idąc za D. Humem, odpowie-dzieli na te pytania przecząco, powołując się m. in. na prawo logiki, że we wniosku nie może być pojęcie, którego nie było w przesłankach. Jeśli więc w przesłankach nie było wyrazu, że należy lub nie należy tak a tak postąpić lub wyrazu równornacznego, nie można z takich przesłanelk wysnuć normy, że tak a tak należy postąpić.

Otóż należy przede wszystkim odróżnić normy od zadań normatywnych, bo normy można wyrazić także w postaci rozkaźników, jak to mamy np. w 10 przykazaniach Dekalogu, a rozkaźniki same przez się nie są zdaniami w znaczeniu logicznym, gdyż nie wyrażają ani zgodności ani sprzeczności z rzeczywistością i nie mogą być ani prawdziwe ani

${ }^{67}$ T. Kotarbiński, Elementy teorii poznania, logiki formalnej $i$ metodologii nauk, Lwów 1929, 262-290.

${ }_{68}$ Styczeń, Antropologia a etyka, 36-38. 
fałszywe - chociaż i co do tego zdania logików są różne. Najbardziej przekonywające wydaje się zdanie T. Kotarbińskiego: „Każdy rozkaźnik ma na widoku coś czemu służy, a co jest zwykle jasne nie bezpośrednio, lecz widnieje dopiero z kontekstu; otóż aby poznać czy dane rozumowanie $\mathrm{z}$ udziałem rozkaźnika jest poprawne, wystarczy zamiast rozkaźnika zalecającego dane działanie, wstawić zdanie stwierdzające celowość zalecanego działania ze względu na to, czemu służy rozkaźnik: np. "nie pij wody $\mathrm{z}$ rowu! - wynika $\mathrm{z}$ wnioskowania: W rowach jest mnóstwo zarazków chorobotwórczych. Więc powstrzymanie się od picia wody z. rowu jest celowe dla zachowania zdrowia" ${ }^{69}$. W podobny sposób św. Tomasz z Akwinu uzasadnia większość zdań normatywnych w swej Sumie, wyprowadzając je ze zdań stwierdzających celowość danego typu postępowania lub jej zaprzeczenia.

Nie jest też prawdą, że powinności nie da się wyprowadzić z bytu, czy raczej że nie można wysnuć zdania, stwierdzającego powinność lub brak jej ze zdań stwierdzających istnienie, cechy lub stosunki jakiejś rzeczywistości. Przecież albo powinność jest czymś, albo jest niczym. Jeśli jest niczym, nie ma sensu mówić o niej; jeśli zaś jest czymś, jest jakimś bytem rzeczywistym, wprawdzie nie samoistnym, podobnie jak barwy, dźwięki, cechy i stosunki - ale właśnie powinność etyc z n a w ujęciu deontologicznym jest rzeczywistym stosunkiem moralnej konieczności uzgodnienia postępowania ludzkiego z naczelną zasadą życia każdego człowieka, a w ujęciu teleologicznym, czyli celowościowym z e mpirycznego punktu widzenia powinnością etyczną nazywamy rzeczywisty stosunek rzeczywistej bezwzględnej lub względnej konieczności określonego postępowania do osiągnięcia w sposób rozumny właściwego celu, nadającego sens życiu ludzkiemu, a mianowicie do zachowania i doskonalenia życia osobowego i społecznego przez rozumne zaspokajanie rzeczywistych potrzeb tegoż życia.

Postępowanie bezwzględnie konieczne do osiągnięcia tego celu jest przedmiotem powinności pozytywnej i tym samym nakazu prawa przyrodzonego; postępowanie uniemożliwiające osiągnięcie powyższego celu jest przedmiotem powinności negatywnej i tym samym $\mathrm{zakazu}$ prawa przyrodzonego. Natomiast możność czynienia tego co jest nakazane przez prawo przyrodzone i tego co nie jest ani nakazane, ani zakazane oraz nieczynienia tego co jest zakazane przez prawo, jest przedmiotem uprawnienia etycznegio. Niekiedy pewien typ postępowania jest tylko względnie konieczny, a mianowicie gdy pośród wielu różnych rodzajów postępowania, prowadzących do zachowania i udoskonalenia życia ludzkiego, urzeczywistnienie przynajmniej jednego z nich,

69 T. Kotarbiński, Istota oceny etycznej, w: Etyka 1, Warszawa 1966, 7-12; O racjonalności rozumowań rozkażnikowych, w: Studia Filozoficzne, 1966, z. 2, 55. 
i to albo obojętnie którego albo bardziej skutecznego, jest niezbędne do osiągnięcia powyższego celu. W tym ostatnim wypadku, gdy chodzi o postępowanie ani zakazane, ani nakazane, ale bardziej skutecznie prowadzące do owego celu mamy lz a l e c e n i e prawa moralinego, jeśli zaś nie jest ani nakazane, ani zakazane, ale utrudnia niepotrzebnie osiągnięcie owego celu, mamy wówczas prawo moralne urzeczywistniać je. Jeśli wreszcie jakieś postępowanie nie pozostaje w żadnym stosunku (ani zgodności ani niezgodności) do powyższego celu, wyznaczonego przez prawo moralne, wówczas jest obojęt ne pod względem etycznym. Wszystkie powyższe terminy: powinność, zakaz, nakaz, uprawnienie, zalecanie, są nazwami rodzajów postępowania (choć tylko pośrednio) do empirycznie poznawalnego zaspokajania potrzeb życia ludzkiego, a więc do jego zachowania oraz doskonalenia.

Niektórzy etycy, np. S. Toulmin, twierdzą, że do uzasadnienia zdań powinnościowych nie nadaje się zwyczajna logika, ale konieczna jest logika szczególna, która by ujmowała zasady etyczne nie jako przesłanki, ale jako prawidła metodyczne w wyprowadzaniu wniosków. Dziś jednak bardziej jest rozpowszechnione przeświadczenie, że do uzasadnienia wielu twierdzeń etycznych wystarczy posługiwanie się zwyczajną dwuwartościową logiką, choć niektórzy zalecają logikę trójwartościową, a nawet logikę pięciowartościową ${ }^{70}$.

Za T. Czeżowskim przyjmujemy, że ,zdania powinnościowe są dla analizy logicznej odmianą zdań modalnych. Można je bowiem przedstawiać jako złożone z funktora modalnego (powinnościowego) „należy”, „wolno" lub jego negacji i argumentu nazwowego lub zdaniowego, oznaczającego czynność, która jest nakazana, dozwolona lub zakazana. Przyjmując niektóre $\mathrm{z}$ owych funktorów jako pierwotne, buduje się aksjomatyczną teorię zdań tego rodzaju jako pewną odmianę logiki zdań modalnych. Według jej twierdzeń, niemniej jak według twierdzeń zwykłej logiki zdań jako zasad wnioskowania, zdania powinnościowe wiążą się ze sobą związkami inferencyjnymi przesłanek i konkluzji" ${ }^{71}$.

Niech litera „x” oznacza określoną osobę lub określoną grupę osób, litera „S" niech oznacza funktor normotwórczy „powinien” lub „należy”, litera „p" nazwę określonego postępowania czy działania w określonych okolicznościach, a litera „N" zaprzeczenie. Analogicznie do kwadratu zdań modalnych możemy przedstawić cztery możliwe stosunki modalne zdań powinnościowych:

${ }^{70}$ W dziedzinie logiki zdań normatywnych oraz uzasadnień etycznych między-. narodowym uznaniem słusznie cieszą się liczne dzieła prof. J. Kalinowskiego, np. Teoria zdań normatywnych, w: Studia Logica, 1953; Le raisonnement juridique et la logique juridique, w: Logique et Analyse, 13 (1970). Liczne artykuły w Archives de Philosophie du Droit i. w innych czasopismach naukowych.

71 T. Czeżowski, Dwojakie normy, w: Etyka I (1966), 146. 


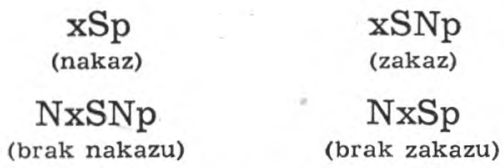

„xSp” czytamy: „x” powinien uczynić „p”; „xSNp”: „x” powinien nie czynić „,p”; „NxSp”: nieprawda, że „x” powinien nie czynić „,p” i wreszcie „NxSp": nieprawda, że „x" powinien czynić „p” (czyli „x" wolno nie czynić „,p”).

Jasne, że między nakazem a zakazem jakiegokolwiek prawa, a więc także prawa przyrodzonego, zachodzi stosunek przeciwieństwa. Dwa zdania więc, z których jedno wyraża nakaz, czyli obowiązek zrobienia czegoś, a drugie wyraża zakaz, czyli powinność nie robienia tego samego i w tych samych okolicznościach, nie mogą być równocześnie prawdziwe ale mogą być równocześnie fałszywe. Np. „x” jest obowiązany pracować w niedzielę" oraz „x" jest obowiązany nie pracować w niedzielę”. Jeśli jedno $\mathrm{z}$ tych zdan jest prawidziwe, drugie musi być fałszywe, ale mogą też oba być fałszzywe, lecz nie mogą być oba równocześnie prawidziwe, bo $\mathrm{x}$-owi może nie być ani nakazane ani zakazane pracować $w$ niedzielę, ale jeśli ma obowiązek pracować $\mathrm{w}$ niedzielę, to nieprawda, że ma obowiązek nie pracować w niedzielę. Między zakazem prawa moralnego czyli powinnością a brakiem nakazu czyli zaprzeczeniem powinności oraz między zakazem a jego zaprzeczeniem zachodzi stosunek sprzeczności, wskutek czego dwa zdania - z których jedno wyraża obowiązek zrobienia czegoś, a drugie zaprzecza istnienie takiego obowiązku, albo $\mathrm{z}$ których jedno stwierdza istnienie obowiązku niezrobienia czegoś, a drugie przeczy jakoby istniał taki związek - nie mogą być równocześnie i w tych samych okolicznościach ani prawdziwe ani fałszywe, a więc np. jeśli komuś wolno nie pracować $w$ niedziele to nieprawda, że jest obowiązany pracować $\mathrm{w}$ niedziele, a jeśli jest obowiązany pracować $\mathrm{w}$ niedziele, to nieprawda, że wolno mu nie pracować $\mathrm{w}$ niedziele, i przeciwnie, jeśli ktoś jest obowiązany nie pracować w niedziele, to nieprawda, że wolno mu pracować, a jeśli mu wolno pracować w niedziele, to nieprawda, że jest obowiązany nie pracować $\mathrm{w}$ niedziele. $\mathrm{Z}$ prawdziwości więc jednego z tych dwu zdań, możemy wnioskować o fałszywości drugiego i z fałszywości jednego możemy wyciągnąć wniosek o prawdziwości drugiego.

Między nakazem prawa przyrodzonego czyli powinnością a brakiem zakazu, oraz między zakazem tegoż prawa a brakiem nakazu, istnieje stosunek podporządkowania. Jeśli więc ktoś na mocy prawa przyrodzonego jest abowiązany zrobić coś, to wollno mu to zrobić, alle nie przeciwnie: z tego, że komuś wolno coś zrobić, np. pracować w niedziele, nie wynika, że ma obowiązek zrobić to, a więc pracować w niedziele. Podobnie $\mathrm{z}$ tego, że ktoś ma obowiązek nie robić czegoś, wynika, że wolno mu nie robić 
tego, ale z tego, że wolno mu nie robić czegoś, nie wynika, że jest zobowiązany nie robić tego - oczywiście zawsze w tych samych okolicznościach. Wreszcie między zaprzeczeniem zakazu i zaprzeczeniem nakazu prawa przyrodzonego, czyli wolnością robienia czegoś i wolnością nierobienia tegoż w tych samych okolicznościach, zachodzi stosunek podprzeciwieństwa. Dwa więc zdania, z których jedno wyraża zaprzeczenie powinności zrobienia czegoś, a drugie zaprzeczenie powinności niezrobienia tegoż w tych samych okolicznościach, mogą być razem prawdziwe, ale nie mogą być równocześnie fałszywe. Z fałszywości więc jednego z nich, można wnioskować o prawdziwości drugiego, ale z prawdziwości jednego z nich nie można wnioskować o fałszywości drugiego; np. z prawdziwości tego zdania, że komuś wolno pracować w niedziele, nie wynika, że wolno mu nie pracować, bo może być obowiązany do pracy $w$ niedziele. Ale z fałszywości zdania, że komuś wolno nie pracować w niedziele, wynika prawdziwość zdania, że wolno mu pracować, w myśl zasady logicznej, że zaprzeczenie zaprzeczenia jest twierdzeniem: „NNSp" jest równoważne ,xSp”, a z ,xSp” wynika „NxSNp”, słownie: zaprzeczenie braku powinności jest stwierdzeniem istnienia powinności zrobienia czegoś, a z tego, że ktoś powinien coś zrobić wynika więc, że wolno mu to zrobić.

W tym schemacie kwadratu zdań powinnościowych, dozwolenie negatywne, że czegoś wolno nie zrobić, definiujemy przez zaprzeczenie powinności zrobienia tego, a dozwolenie pozytywne, że wolno coś zrobić, wyrażamy zaprzeczeniem obowiązku nierobienia tego. Schemat ten jest równoznaczny schematowi, który za G. H. Wright'em przyjął Z. Ziembiński, z tą tylko różnicą, że Z. Ziembiński umiesizcza funktor powinnościowy przed schematem i wyróżnia cztery funktory: „N” na oznaczenie nakazu, „Z" na oznaczenie zakazu, „D” na oznaczenie dozwolenia pozytywnego i ,F” na oznaczenie postępowania fakultatywnego, podczas gdy my wszystkie cztery funktory sprowadzamy do jednego ,S” przy pomocy znaku zaprzeczenia „N”, tak że np. jego wyrażenie „Dncx”, który się czyta: czyn ,c” jest prawnie dozwolony dla „x” ze względu na normę ,n", piszemy: „NxSNp”, który czytamy: nieprawda, że „x" jest obowiązany nie czynić ,p", czyli nie ma zakazu robienia „p”, lub jeszcze inaczej wolno czynić ,p”. Nie zgadzamy się natomiast z diefinicją Ziembińskiego, jakoby postępowanie obojętne pod względem prawnym było równoważne koniunkcji zaprzeczenia nakazu i zaprzeczenia zakazu. Np. jeśli ktoś prawnie jest obowiązany zapłacić robotnikowi 1.000 zł, ale wiedząc, że ów robotnik jest biedny, zapłaci mu dobrowolnie 2.000 zł, choć nie było ani nakazu ani zakazu wypłacenia mu tyle, czyn jego bynajmniej nie jest obojętny prawnie, przynajmniej gdy chodzi o prawo moralne, lecz jest czynem moralnie dobrym, jeśli wszystkie inne okolicz- 
ności są zgodne z prawem moralnym, np. jeśli wypłacając o tysiąc zł więcej, niż był obowiązany, nie krzywdzi innych ludzi ${ }^{72}$.

Dowodzenie na podstawie kwadratu funktorów powinnościowych może być bardzo pożytecznym, a niekiedy koniecznym środkiem w przeprowadzaniu bardziej uwikłanych uzasadnień zdań normatywnych, wysnutych z prawa przyrodzonego, ale samo przez się nie wystarczy do wyprowadzania konkretnych wytycznych tegoż prawa, pojętego jako fakt empirycznie stwierdzalny $\mathrm{w}$ postaci prawidłowego uporządkowania składników, uzdolnień i slzłonności ludzkiej osoby, skierowanych ku zachowaniu i doskonaleniu życia osobowego i społecznego przez rozumne zaspokajanie rzeczywistych potrzeb tego życia. Przyjmujemy, że ze zdań nienormatywnych, wyrażających jakiś fakt (zdarzenie, rzecz, cechę, stosunek), a więc nie zawierających funktorów normotwórczych, takich jak „należy”, „powinien”, „ma obowiązek” itp., nie można wyprowadzać zdań normatywnych nietautologicznych, jeśli owe zdanie z pozoru nienormatywne nie jest równoznaczne $\mathrm{z}$ odpowiednim zdaniem normatywnym na podstawie poprawnego zastąpienia funktoru normotwórczego czy powinnościowego przez równoznaczne wyrażenie nienormatywne, np. „x powinien czynić p" w naszym ujęciu empirrycznym jest równoznaczne wyrażeniu: „czynienie „p" dla x-a jest konieczne do zachowania i doskonalenia życia osobowego i społecznego", a „x" powinien nie czynić „p" jest w tym ujęciu równoznaczne z wyrażeniem: „czynienie „p" sprzeciwia się zachowaniu i doskonaleniu życia $\mathrm{x}$-a"; podobnie wyrażenie: „x-owi wolno czynić ,pp” (na mocy prawa przyrodzonego) znaczy: „postępowanie „p" x-a nie sprzeciwia się zachowaniu i doskonaleniu osobowego i społecznego życia ludzkiego".

Zwolennicy celowościowego kierunku etyki przyjmują w uzasadnienianiu jej tez, przynajmıniej milcząco, takie właśnie zastąpienie funiktora normotwórczego, albo wyprowadzają je z sylogizmu, w którym przynajmniej jedna przesłanka w sposób jawny lub domyślny zawiera funktor normotwórczy: „należy”, „nie należy”, „wolno”, „nie wolno”. Taką przesłanką bywa zazwyczaj jakaś naczelna zasada etyki.

Różni etycy zalecali różne naczelne zasady życia moralnego. Np. hedoniści za Epikurem głosili: „nie można żyć przyjemnie, nie żyjąc rozumnie, pięknie i sprawiedliwie, ani też żyć rozumnie, pięknie i sprawiedliwie, nie żyjąc przyjemnie" "73. Utylitaryści za J. S. Millem, zalecają każdemu: „Postępuj tak, aby twoja działəlność mogła rzeczywiście albo prawdopodobnie przysporzyć jak najwięcej szczęścia dla jak naj-

72 Z. Ziembiński, Próba uporządkowania podstawowego stownictwa prawniczego, w: Studia Logica, 15 (1964), 264.

${ }_{73}$ List Epikura do Menoikeusa, cyt. za A. Krokliewicz, Nauka Epikura, Kraków $1929,386$. 
większej ilości ludzi” "74. Komuniści, za K. Marksem, głoszą: „Człowiek jest najwyższą istotą dla człowieka”, a „dobrem moralnym jest wszystko to, co sprzyja jego rozwojowi" ${ }^{75}$. Cz. Znamierowski twierdzi: ,jedyną naczelną normą, jaką wyznacza życzliwość powszechna, jest to, że każdy człowiek powinien być życzliwy powszechnie i życzliwością tą powinien się kierować w każdym akcie woli" " ${ }^{76}$. T. Kotarbiński zaleca ideał spolegliwego opiekuństwa: „Wszystko co zasługuje na ocenę moralną dodatnią mieści się w charakterystyce usposobienia człowieka, na którego można liczyć jako na towarzysza lub opiekuna w trudnych i niebezpiecznych okolicznościach, wszystko zaś, co zasługuje na ocenę moralną ujemną, sprowadza się do piętnowania motywacji o charakterze przeciwnym" "7. Ks. kard. K. Wojtyła zaleca: „Ilekroć w twoim postępowaniu osoba jest przedmiotem działania, tylekroć pamiętaj, że nie możesz jej traktować tylko jako środka do celu, jako narzędzia, ale liczyć się z tym, że ona. sama ma lub powinna mieć swój cel. Zasada ta w takim sformułowaniu stoi u podstaw wszelkiej właściwie pojętej zdolności człowieka, a zwłaszcza wolności sumienia" "7. Najbardziej jednak znaną naczelną zasadą moralną jest imperatyw kategoryczny E. Kanta: „,postępuj tak, jak gdyby maksyma twojego postępowania przez wolę twą miała się stać ogólnym prawem przyrody" "

Te i inne zalecenia są bardzo piękne i słuszne, jeśli są dobrze rozumiane i należycie stosowane, ale ich zakres jest zawężony do pewnych tylko rodzajów postępowania moralnego; nie obejmują one np. potrzeby właściwego stosunku do siebie samego, do własnych myśli, uczuć i pragnień, do Boga. „Ich rzekoma powszechność nie może być udowodniona tym tylko, że służą one zaspokojeniu pewnych wspólnych wszystkim ludziom potrzeb", jak o niektórych z nich stwierdza M. Ossowska ${ }^{80}$.

Czy jest rzeczą możliwą sformułowanie prawdziwie naczelnej i powszechnie ważnej zasady $\mathrm{w}$ oparciu nie o założenia metafizyczne, ale o fakty stwierdzalne empirycznie? Zwolennicy deontologicznego ujęcia etyki odpowiadają na to pytanie zazwyczaj przecząco z wyjątkiem tych, którzy pojęcie poznania empirycznego rozciągają także na intuicję umysłową i uznają moralność za przedmiot umysłowego doświadczenia czy „kontaktu poznawczego". Są bowiem przeświadczeni, że z przesłanek

74 Por. Kotarbiński, Utylitaryzm w etyce Milla $i$ Spencera, 60.

75 M. Michalik, Etyka marksizmu i moralność socjalistyczna, w: Etyka, Warszawa $1973,247$.

${ }^{7} \mathrm{Cz}$. Znamierowski, Naczelna norma moralna $i$ jej pochodne, w: Studia Filozoficzne, 1957 , z. 3, 97.

77 T. Kotarbiński, Śtudia z zakresu filozofii, etyki $i$ nauk społecznych, Ossolineum 1970, 236.

$78 \mathrm{Ks}$. kard. K. Wojtyła, Miłość i odpowiedzialność, Kraków, 18.

79 Kant, Krytyka praktycznego rozumu, 40.

80 M. Ossowska, Zagadnienie powszechnie uznanych norm moralnych, w: Studia Filozoficzne, 1957, z. 3, 87. 
empirycznych, jako stwierdzających jedynie to co jest, nie można wyprowadzić żadnej zasady, głoszącej jak powinno być. Jeśli jednak uzna się powinność moralną oraz uprawnienia moralne ludzi za coś realnego a więc za rzeczywiście istniejący stosunek postępowania ludzkiego do osiągnięcia rzeczywistego celu ostatecznego ludzi, czyli do zachowania i doskonalenia życia osobowego i społecznego (w ujęciu empirycznym), wydaje się, że sformułowanie takiej zasady jest możliwe.

Najogólniejsza zasada postępowania ludzkiego powinna być tak sformułowana, by jej orzeczenie swym zakresem obejmowało wszy:stkie możliwe rodzaje postępowania, wszystko co należy czynić lub nie należy czynić, co wolno i nie wolno robić, a podmiot tej zasady, względnie przedmiot jej orzeczenia w nieosobowym ujęciu, wyrażał najogólniejszy powód, dlaczego coś należy lub wolno czynić, względnie nie należy i nie wolno czynić. Takim najogólniejszym kryterium jest to, że dane postępowanie jest dobre, a więc $\mathrm{w}$ empirycznym ujęciu prowadzi do zachowania i doskonalenia życia ludzkiego przez rozumne zaspokajanie jego potrzeb. Innymi słowy, taka zasada powinna brzmieć: „N a l e ży c z ynić to co dobre i nie czynić tego co złe”. Taką właśnie zasadę przyjął św. Tomasz jako naczelną dla zasad prawa naturalnego: „Wszelki sprawca działa dla jakiegoś celu, którym jest dobro. Dlatego pierwszą zasadą rozumu w dziedzinie postępowania praktycznego opartą na pojęciu dobra przez wszystkich pożądanego, jest następująca: dobro należy czynić, a zła należy unikać. Na tej zasadzie opierają się wszystkie przykazania prawa naturalnego" ${ }^{81}$. Tę zasadę, wyrażoną bezosobowo, można wyrazić w stronie biernej: dobro jest tym, co należy czynić, a zło tym czego nie należy czynić. Tak sformułowana zasada jest ważna nie tylko w etyce, ale w każdej umiejętności praktycznej, np. w technice, jeśli przez dobro rozumie się cel, gdyż w każdej z nich podaje się co należy zrobić, by nastąpił pożądany skutek, innymi słowy wskazuje się to, co jest warunkiem bezwzględnie koniecznym, czyli niezbędnym albo składnikiem dopełniającym warunku wystarczającego określonego późniejszego zdarzenia - jak mówi T. Kotarbiński ${ }^{82}$.

W języku etyki wyraz „należy” jest równoznaczny z wyrazem ,powinno się", a ponieważ podmiotem powinności jest każdy człowiek zdolny do używania rozumu, jest rzeczą oczywistą, że domyślnym podmiotem zdania, wyrażającego tę najogólniejszą zasadę prakseologiczną, jest każdy człowiek zdolny do rozumnego postępowania. Stwierdzenie powinności lub jej zaprzeczenie jest orzeczeniem tej zasady, a podmiotem tej powinności jest dobro względnie zło. Tym dobrem, względnie złem, nie jest jakaś rzecz fizyczna, ale dobre względnie złe postępowanie czło-

81 Summa Theologica, I-II, q. 94, a. 2.

${ }^{82}$ T. Kotarbiński, Zdania prakseologiczne, w: Studia Filozoficzne, 1960, z. 4, 4. 
wieka, które należy lub nie należy urzeczywistnić w konkretnych warunkach życia ludzkiego. W zakresie etyki więc tę najogólniejszą zasadę prakseologiczną można zawęzić do następującego sformułowania: Każdy człowiek, zdolny do używania rozumu, powinien urzeczywistniać postępowanie dobre, a nie urzeczywistniać postępowania złego. Skoro zaś z empirycznego punktu widzenia, postępowanie dobre to takie, które zaspokajając rozumnie potrzeby ludzkie, prowadzi do zachowania i doskonalenia życia osobowego i społecznego, postępowanie zaś złe to takie, które sprzeciwia się zachowaniu i doskonaleniu życia ludzkiego, a tym samym rozumnemu zaspokajaniu jego potrzeb, można jeszcze bardziej zawęzić ową zasadę $\mathrm{w}$ sformułowaniu: każdy człowiek powinien czynić to, co w konkretnych okolicznościach doskonali życie ludzkie osobowe i społeczne, rozumnie zaspokajając jego potrzeby, i powinien unikać tego co się sprzeciwia temu doskonaleniu.

Stosując przyzdaniowe zaprzeczenie nakazu i zakazu, zgodnie $\mathrm{z}$ wyżej podanym schematem kwadratu zdań powinnościowych, możemy otrzymać z owej najpowszechniejszej zasady prakseologicznej bezpośrednie wnioski o powinnościach oraz uprawnieniach moralnych, czyli o tym co człowiekowi wolno czynić i o tym, czego nie wolno mu czynić. Te wnioski z kolei można przyjąć za przesłanki, z których dadzą się wysnuć dalsze wnioski przy pomocy innych przesłanek już to analitycznych, już to syntetycznych. Jak wiadomo przesłanki analityczne $\mathrm{w}$ terminologii Kanta to zdania, w których orzecznik zawiera się $\mathrm{w}$ pojęciu podmiotu, względnie to zdania, których prawdziwość wynika $\mathrm{z}$ sensu występujących w nim wyrazów, określonego np. przez umowę lub przez zwyczaj, choć niekiedy, jak wykazał K. Ajdukiewicz ${ }^{83}$, prawdziwość niektórych zdań analitycznych jest zależna także od doświadczenia.

Zdania analityczne więc są $\mathrm{w}$ nauce tym, czym mikroskop w obserwacjach przy pomocy wzroku: nie dodaje niczego do przedmiotu badanego, ale pozwala widzieć to, czego nie można zobaczyć bez niego. Tak samo zdania analityczne, będące przesłankami w stosunku do jakiejś zasady, pozwalają głębiej i dokładniej ująć jej treść, nie dodając do niej niczego, co by już nie było uwikłane w niej. Natomiast zdania syntetyczne to takie sądy, których prawdziwość nie wynika z samego znaczenia występujących w nim wyrazów, ale np. z doświadczenia, czy jakiegokolwiek innego spostrzegania.

Mogą być jednak zdania, które pod pewnym względem są analityczne, a pod innym względem są syntetyczne, gdy ich prawdziwość wynika nie tylko ze znaczenia samych wyrazów, z których są zbudowane, ale także ze spostrzeżeń empirycznych, które je potwierdzają, np. wiele

${ }^{83}$ Cyt. za H. Morinerową, Uwagi na temat sporu o analityczny charakter niektórych twierdzeń nauk przyrodniczych, w: Studia Filozoficzne, 1960, z. 1, 102. 
twierdzeń geometrycznych oraz fizycznych, zwłaszcza z zakresu mechaniki. To że w ruchu jednostajnie przyspieszonym bez prędkości początkowej droga jest wprost proporcjonalna do kwadratu czasu, da się wywieźć z samego pojęcia przyspieszenia, abstrahując od jego istnienia, ale jego istnienie potwierdza tę zasadę empirycznie.

Otóż podobnie rzecz się ma z wielką ilością tez etycznych, wysnutych z naczelnej zasady prawa przyrodzonego przy pomocy przesłanek analitycznych, np. definicji, których prawdziwość wynika z sensu wyrazów, jakie w nich występują na mocy semantycznych reguł języka ustalonych przez potoczny zwyczaj lub przez jawną albo domyślną umowę a z drugiej strony wyrażających jakiś fakt lub zespół faktów, cech, stosunków, stwierdzalnych empirycznie, np. określając roztropność przez nazwanie takiego zespołu faktów jak te, że niektórzy ludzie są sprawni w wyszukiwaniu, rozsądzaniu i stosowaniu właściwych środków do osiągnięcia odpowiedniego celu; podobnie gdy sprawiedliwością nazywa się spostrzegalny fakt, że niektórzy ludzie są sprawni w oddawaniu każdemu tego, co się mu należy, albo męstwem nazywając zespół faktów, że wielu ludzi spełnia swe obowiązki, przezwyciężając strach, nawet w niebezpieczeństwie śmierci itp. $\mathrm{Z}$ tak zbudowanych definicji, przy pomocy innych zdań analitycznych, zwłaszcza takich, których prawdziwość wynika nie tylko ze znaczenia występujących w nich wyrazów, ale także ze spostrzeganych faktów - można wyprowadzić tysiące ważnych wniosków, odnoszących się np. do określenia przedmiotów poszczególnych sprawności moralnych, czyli cnót, wyliczenia ich rodzajów i składników, ịch przyczyn i następstw itp. - podobnie jak z definicji trójkąta i kilku aksjomatów można wyprowadzić całą trygonometrię.

Zespół wniosków wysnutych z najogólniejszej naczelnej zasady prawa przyrodzonego: Należy czynić to co dobre i należy nie czynić tego co złe, a więc z empirycznego punktu widzenia: urzeczywistniać takie postępowanie, które rozumnie zaspokajając potrzeby ludzkie prowadzi do zachowania i doskonalenia osobowego i społecznego życia ludzkiego stanowi etykę normatywną bardzo ogólnikową i teoretyczną. Ale nic nie wzbrania $\mathrm{z}$ owej zasady, względnie $\mathrm{z}$ analitycznych wniosków wysnutych z niej, wyprowadzać dalsze wnioski przy pomocy zdań syntetycznych, a więc takich, których prawdziwość można stwierdzić na podstawie obserwacji faktów stwierdzonych empirycznie. Mogą to być już to oceny, gdy owe przesłanki określają jawnie lub domyślnie podmiot naczelnej zasady, ã więc dobro względnie zło moralne określonego postępowania, stwierdzając, że takie a takie postępowanie jest godziwe, sprawiedliwe, roztropne, mężne itd. - już to zdania normatywne, gdy w ich orzeczeniach występuje jawnie lub domyślnie orzeczenie naczelnej zasady: „należy czynić" lub, ,należy nie czynić” albo zaprzeczenie tychże orzeczni- 
ków: „nieprawda, że należy nie czynić” czyli „wolno czynić” lub „nieprawda, że należy czynić” czyli „wolno nie czynić”.

Oczywiście nie będą to zdania normatywne tetyczne, czyli oparte na stanowieniu ustawodawcy lub przełożonego, ale aksjologicznie, czyli oparte na wartościowaniu, wyrażonemu w ocenie. Np. gdy ktoś rozumuje w ten sposób: Tego co złe nie należy czynić. Codzienne picie wódki jest złe, bo nierozumnie szkodzi zdrowiu. A więc nie należy codziennie pić wódki. Do aksjologicznych uzasadnień zdań normatywnych sprowadza się również teleologicznie, czyli celościowe ich uzasadnianie, gdyż konieczność lub przydatność jakiegoś sposobu postępowania do osiągnięcia jakiegoś określonego celu jest wartością tegoż postępowania ${ }^{84}$.

Oczywiście, zarówno oceny jak i zdania normatywne, wysnute $\mathrm{z}$ owej naczelnej zasady prawa przyrodzonego, będą miały taką wartość logiczną, jaką mają owe przesłanki, przy pomocy których zostały wysnute.

Ale czy oceny, a więc zdania aksjologiczne, mogą być podstawą do wysnuwania $\mathrm{z}$ nich zdań normatywnych, a szczególniej powinnościowych, nie utożsamiając powinności z wartościowością? Przecież czym innym jest wartość jakiegoś postępowania, a czym innym jest powinność jego urzeczywistnienia. Nie można uznać za równoznaczne zdania: „A powinno być B" i ,tylko A, które jest B, jest dobrym A" np. w przykładzie B. Russella: „żołnierz powinien być dzielny” i ,tylko żołnierz dzielny jest dobrym żołnierzem" ${ }^{85}$.

To prawda, że oceny nie da się przekształcić w normę, ale z tego nie wynika, by z oceny nie dało się wyprowadzić zdania normatywnego przy pomocy przesłanki określającej funktor normotwórczy terminami wyrażającymi ocenę lub jej równoważnik opisowy. Jeśli np. powiemy, że postępowanie „,p" jest dobre moralnie, bo jest niezbędne do zaspokojenia jakłiejś potrzeby życia ludzkiego w sposólb rozumny - i równacześnie przyjmiemy, że to postępowanie, które w sposób rozumny zaspokaja jakieś potrzeby życia ludzkiego jest powinnością moralną, wówczas możemy przyjąć również wniosek wynikający z tych dwóch przesłanek, a mianowicie, że urzeczywistnienie postępowania „p” jest powinnością moralną. Można wprawdzie niekiedy uznać, że „postępowanie „p” jest piękne, wzniosłe, dobre, ale nie powinno być urzeczywistnione", bo w tej chwili jest niepotrzebne, a może być nawet szkodliwe, jeżeli piękność, wzniosłość czy dobroć rozumie się $\mathrm{w}$ sensie metafizycznym lub estetycznym, a nie w sensie moralnym, w którym za dobre, piękne, wzniosłe uznaje się tylko takie postępowanie, które w tych a tych konkretnych okolicznościach jest takie. Np. narażenie własnego życia dla uratowania

${ }^{84}$ Z. Ziembiński, Normy etyczne a normy aksjologiczne $w$ koncepcji Cz. Znamierowskiego, w: Studia Filozoficzne, 33 (1963), z. 2, 87-112.

${ }^{85}$ Cyt. za Cz. Porębskim, art. cyt. $177-196$. 
cudzego życia jest postępowaniem moralnie dobrym, pięknym i wzniosłym, ale jedynie wtedy, gdy wszystkie inne okoliczności są moralnie godziwe, a więc $\mathrm{w}$ tym wypadku, jeśli jest nadzieja, że narażając siebie, uratuje się drugiego i nie ma innego sposobu uratowania drugiego prócz narażenia własnego życia. Tak więc, jeśli przez postępowanie moralnie dobre rozumie się postępowanie bezwzględnie lub względnie konieczne do zachowania lub doskonalenia życia ludzkiego, a przez powinność moralną rozumie się taką konieczność, wówczas ocenę takiego postępowania można uznać za przesłankę do wysnucia powinnościowego.

Jasne, że powinności moralnej nie utożsamiamy z każdym wymaganiem, np. z wymaganiem prawa pozytywnego, nie sądzimy, że „,dobre” znaczy tyle co „wymagane”, „potrzebne”, „konieczne” w ogólnym znaczeniu tych przymiotników. Ale też nie możemy się zgodzić z takim zdaniem, iż: „wszyscy widzą, że niezbędną do wykonywania pewnych określonych funkcji społecznych bywa właśnie brutalność, przemoc, okrucieństwo, bezwzględność, brak wyobraźni, i że gani się wtedy łagodność i subtelność u człowieka, mającego wypełniać taką rolę, gdyż te cechy stanowią tutaj czasem znaczną przeszkodę oraz źródło ewentualnych szkód społecznych". Kaci z obozów koncentracyjnych, którzy jeszcze żyją $\mathrm{w}$ wielu krajach, powinny wystawić autorowi tego zdania pomnik wdzięczności ${ }^{86}$.

We wnioskowaniu na podstawie owej najogólniejszej zasady prakseologicznej druga przesłanka albo stanowi podstawienie orzeczenia owej zasady, zastępując je innym równoznacznym wyrażeniem, np. zastępując „należy czynić” przez ,jest obowiązkiem zrobić”, a „należy nie czynić" wyrażeniem ,powinno się unikać" itp. — albo określa przedmiot tego orzeczenia (względnie podmiot tejże zasady, wyrażonej w stronie biernej), a więc wyraża co jest dobrem, a co jest złem. W pierwszym wypadku ta druga przesłanka podobnie jak i zasada, będzie zdaniem normatywnym, a wniosek, wysnuty $\mathrm{z}$ owej zasady przy pomocy takiej przesłanki, będzie wyrażał to samo co owa zasada, tylko innymi słowami, względnie zacieśni jej treść i jej najogólniejszy zakres, obejmujący wszelkie postępowanie, do postępowania prawnego lub etycznego, np.: Nie należy czynić tego "co złe. Otóż „nie należy czynić” znaczy to samo co „powinno się nie robić”. A więc zła nie powinno się robić. Natomiast w drugim wypadku przesłanką jest zazwyczaj jakaś ocena prakkseiologiczna, a wniosek wysnuty przy jej pomocy będzie również zdianiem normatywnym etycznym, prawnym, czy nawet technologicznym. Np. to co dobre należy czynić. Otóż wysiłki, by uratować człowieka tonącego, uzgadniać przepisy władz wykonawczych z postanowieniami kon-

${ }^{86}$ J. Szewczyk, Zagadnienie zależności wzajemnej ocen $i$ norm, w: Studia Filozoficzne, 1964, z. 4, 134. 
stytucji, stosować żelazobeton przy budowie mostu, są dobre (moralnie, prawnie technicznie). A więc należy czynić owe wysiłki.

Najogólniejszy schemat wszelkiego wnioskowania prakseologicznego można ująć następująco: To co dobre należy czynić, a tego co złe należy nie czynić.

$$
\begin{aligned}
& \text { Otóż „,p" jest dobre, a „," jest złe. } \\
& \text { Więc należy czynić „,p" nie çzynić „,q". }
\end{aligned}
$$

$\mathrm{W}$ tym schemacie wszystko zależy od tego, co się $\mathrm{w}$ etyce rozumie przez „dobre” i ,złe”: czy zgodność lub niezgodność z jakimś imperatywem kategorycznym lub hipotetycznym, jak chcą niektórzy zwolennicy deontologicznego kierunku etyki, czy też zgodność lub niezgodność postępowania z naczelnym celem życia ludzkiego, jak wolą zwolennicy celowościowego, czyli teleologicznego ujmowania etyki, oceniając wartość postępowania ludzkiego podług tego, czy jest środkiem lub warunkiem koniecznym względnie wystarczającym do osiągnięcia owego naczelnego celu.

Jeśli z empirycznego punktu widzenia tym naczelnym celem, ku któremu są skierowane przyrodzone skłonności człowieka jest doskonalenie życia ludzkiego osobowego i społecznego przez rozumne zaspokajanie jego potrzeb (w pojęciu doskonalenia życia mieści się pojęcie jego zachowania), możemy uznać za słuszną i analityczną przesłankę: postępowanie, które doskonali życie ludzkie osobowe i społeczne lub jest bezwzględnie lub względnie konieczne do tego doskonalenia, zaspokajając jego potrzeby cielesne i duchowe, jest moralnie dobre, a postępowanie, które temu doskonaleniu życia ludzkiego sprzeciwia się, jest moralnie złe. Przy pomocy zaś tej przesłanki można z najogólniejszej zasady prakseologicznej wyprowadzić wniosek: należy czynić to, co doskonali życie ludzkie osobowe i społeczne lub jest bezwzględnie lub względnie konieczne do tego doskonalenia przez rozumne zaspokajanie potrzeb tegoż życia. Otóż tym, co doskonali życie ludzkie są sprawności umysłowe i moralne, osobowe i społeczne, gdyż one są po prostu składnikami doskonałości, koniecznym zaś warunkiem i środkiem ich zdobywania są takie czynności, które rozumnie zaspokajają cielesne i duchowe potrzeby życia ludzkiego.

Przesłanki, stwierdzające, że takie a takie postępowanie doskonali życie ludzkie lub jest bezwzględnie lub względnie konieczne do tego doskonalenia przez zaspokajanie jego potrzeb, mogą być z kolei już to analityczne, a więc prawdziwe na podstawie znaczenia samych wyrazów, z których są zbudowane, np. w postaci definicji jakiejś sprawności moralnej lub opartego na niej podziału, określenia jej podmiotu i przedmiotu, jej zadania i stosunku do innych sprawności - już to syntetyczne, a więc oparte nie na samym znaczeniu wyrazów czy 
na oczywistości, wynikającej z przyjętej definicji, ale na podstawie faktów stwierdzalnych empirycznie.

W pierwszym przypadku wnioski, wyprowadzone z naczelnej zasady przy pomocy tych analitycznych przesłanek, będą również analityczne i będą posiadać wszystkie cechy zdań analitycznych, a więc będą powszechne, obiektywne i niezmienne, podobnie jak wszystkie inne zdania analityczne, np. w logice lub w matematyce, (jeśli oczywiście będą wysnute $\mathrm{z}$ tych analitycznych przesłanek przez ścisłe wnioskowanie). Otóż ogromna większość tez etycznych, zawartych w II części Sumy Teologicznej św. Tomasza to właśnie tego rodzaju wnioski z analitycznych zasad, wysnute przy pomocy analitycznych przesłanek, najczęściej opartych na definicjach poszczególnych sprawności. Fakt zaś, że definicje Tomaszowe wyrażają rzeczywistość empirycznie stwierdzalną u wielu ludzi, iż np. oddają każdemu, co się mu należy (sprawiedliwość), że nie postępują lekkomyślnie, ale po rozwadze i namyśle stosują właściwe 'środki do zamierzonego naczelnego celu (roztropność), że spełniają swe obowiązki, przezwyciężając strach nawet $\mathrm{w}$ niebezpieczeństwie śmierci (męstwo) itp. - nie zmienia analitycznego charakteru zdań, wyrażających te definicje, podobnie jak fakt, że z wielkim przybliżeniem można stwierdzić mierzeniem przy pomocy kątomierza prawdziwość 'twierdzenia, że suma kątów w trójkącie jest równa dwom kątom prostym, nie zmienia faktu, że twierdzenie to jest analityczne.

Natomiast wnioski, wysnute $\mathrm{z}$ najogólniejszej zasady prakseologicznej, względnie ze zdania analitycznego, będącego jej poprawnym podstawieniem, przy pomocy przesłanki syntetycznej, będą miały taką wartość logiczną, jaką ma owa przesłanka, a więc ich powszechność oraz niezmienność będzie względna w miarę, jak rzeczywiste potrzeby życia ludzkiego są lub nie są wspólne wszystkim ludziom wszystkich czasów, a ich rozumne zaspokojenie, a tym samym sposób doskonalenia życia ludzkiego, może i musi ulegać zmianom zależnie od najrozmaitszych okoliczności czasu i miejsca. Chociaż bowiem wiele jest potrzeb wspólnych wszystkim ludziom wszystkich czasów, np. konieczność odżywiania się, oddychania, zdobywania wiedzy, kochania, sprawiedliwości itp., niemniej konkretne sposoby zaspokajania tych i innych potrzeb mogą być różne w różnych czasach i różnych krajach. Np. chodzenie w ciepłym ubraniu (w kożuchu, futrze itp.) jest nakazem prawa przyrodzonego na Alasce, w Grenlandii, na Antarktydzie, ale zakazem tego prawa w Afryce podzwrotnikowej, przynajmniej w czasie upałów słonecznych, bo w pierwszym wypadku jest konieczne do zachowania życia, a w drugim mu się sprzeciwia. Podobnie małżeństwo braci z siostrami wówczas kiedy nie było innych kobiet (za Adama i Ewy) było rozumnym zaspokojeniem potrzeby zachowania życia gatunku ludzkiego, a więc i nakazem prawa 
przyrodzonego. Dziś tego rodzaju małżeństwo jest zakazem tegoż prawa przyrodzonego nie tylko ze względu na niebezpieczeństwo dziedziczenia genów szkodliwych, lecz także ze względu na konieczność życia społecznego $\mathrm{z}$ innymi.

Ponieważ konkretne postępowanie człowieka jest zależne od zmiennych okoliczności, w których dokonuje się, przy wartościowaniu tegoż postępowania oraz przy decydowaniu się, jạk należy w tym konkretnie położeniu uczynić, nie można obejść się w dziedzinie moralności ani bez przesłanek analitycznych, przynajmniej w postaci owej najogólniejszej zasady prakseologicznej, że należy czynić to co dobre, a nie czynić tego co złe - ani bez przesłanek syntetycznych, które wskazują, co w danych konkretnych okolicznościach jest dobre lub złe, bo rozumnie lub nierozumnie zaspokaja albo nie zaspokaja potrzeb życia ludzkiego, bardzo często to, co jedni uznają za dobre, inni, nawet moraliści, uważają za złe. Np. św. Tomasz za Juliuszem Cezarem powiada, że starożytni Germanie łotrostwo, dokonane na innych ludziach, poczytywali za cnotę ${ }^{87}$.

Sam św. Tomasz twierdzi, że pierwsze najogólniejsze zasady prawa naturalnego są powszechnie znane i są powszechnie słuszne, bo wszyscy mają te same podstawowe skłonności do zaspokajania zasadniczych potrzeb, wspólnych wszystkim ludziom. „Ale im bardziej schodzi się do szczegółów, tym większa jest rozbieżność zdań, gdyż im liczniejsze są uwarunkowania, tym liczniejsze mogą być sposoby niedomagania" " ${ }^{88}$. Stąd Akwinata wyprowadza wniosek, że pierwsze zasady prawa naturalnego są niezmienne, natomiast wtórne, a więc takie, które są wnioskami, wysnutymi z pierwszych zasad, wyrażają to, co nà ogół jest słuszne, ale w poszczególnych wypadkach może niekiedy zawodzić wskutek zaistnienia przeszkód w ich zachowaniu.

Nic więc dziwnego, że nawet między moralistami istnieją spory; gdy chodzi o wartość moralną takich czynności, jak stosowanie środków antykoncepcyjnych, użycie bomby atomowej, kara śmierci, zabijanie jeńców, gdy nie można ich zabrać do obozu itd. Kto ma rozstrzygać tego rodzaju wątpliwości sumienia? Dla katolików są miarodajne zalecenia Kościoła, choć te zalecenia są często zbyt ogólnikowe; dla innych ważne są tylko ustawy państwowe i rozkazy władz, choć te nieraz bywają niesprawiedliwe. Dla wszystkich również powinny być miarodajne wyniki nauk empirycznych, stwierdzających rzetelnie, czy dany typ postępowania naprawdę doskonali cielesne, a przede wszystkim duchowe życie tak poszczególnych osób, jak i całej ludzkości - ale na takie rzetelne wyniki nauk empirycznych trzeba często długo czekać. Tymczasem zaś należy prosić Ducha św. o światło i postępować tak, jak nakazuje su-

${ }^{87}$ Summa Theologica, I-II, q. 94, a. 4.

${ }^{83}$ Tamże. 
mienie oświecone wiarą, zgodnie z przykazaniem Jezusa Chrystusa: „Bądźcie więc doskonali, jak doskonały jest Ojciec wasz niebieski” (Mt $5,48)^{89}$.

\section{LA CONCEPTION EMPIRIQUE DE LA LOI NATURELLE}

$R$ és u mé

Comme par l'analyse de la structure et du fonctionnement de la montre on peut savoir comment il faut traiter cet instrument pour assurer la réalisation de son but, de même l'analyse de la structure et du fonctionnement de la personnalité humaine nous fournit des données empiriques dont l'interprétation permet de connaître comment il faut se comporter pour satisfaire les besoins de la vie humaine personnelle et sociale. L'observation de la vie humaine conduit à la découverte empirique de la coordination de diverses forces psycho-physiques et de diverses capacités nécessaires à cette satisfaction et au perfectionnement de la vie humaine.

Cette coordination entre les forces psycho-physiques et entre les capacités humaines dont l'analyse permet de connaître comment il faut se comporter pour atteindre le bien commun de cet ensemble (qui est chaque personne humaine et chaque societé) à travers la satisfaction des besoins de la vie personnelle et sociale, c'est-à-dire, pour atteindre la perfection de la vie humaine, s'appelle la $10 \mathrm{i}$ naturelle dans le sens empirique de ce mot. On l'appelle ,naturelle' parce qu'elle dérive de la structure de la nature humaine prise au sens de principe de l'activité propre aux hommes en les rendant capables de raissonner, de vouloir et d'agir conformément aux exigences de la raison. C'est pourquoi la loi naturelle n'est pas ni un code rédigé une fois pour toutes ni l'ensemble des règles valables pour tous les hommes de tout temps et de tout lieu, bien qu'elle contienne un fondement pour ces règles.

L'existence de cette loi résulte surtout du fait de l'existence d'une coordination entre les inclinations naturelles et particulièrement celles qui sont communes à tous les hommes et uniquement aux hommes et résultent de leur rationnalité radicale, c'est-à-dire de la capacité de raisonner et d'agir raisonnablement et librement quand leur système nerveux n'est pas bloqué par un développement insuffisant, par une maladie, par le sommeil, etc Telles sont les inclinations à utiliser la raison, la volonté e la langage, la tendance à recherches des biens spirituels, tels que des sciences, des arts, des vertus morales.

Les inclinations ne sont vraiment naturelles chez les hommes que si elles sont conformes au principe distinctif et spécifique de la nature humaine, c'est-à-dire, à la raison. Elles ne constituent pas des normes morales puisque aucune tendance est sa norme; elles poussent les hommes à quelques actions déterminées et suggèrent ainsi à la raison le jugement estimatif selon lequel tel ou tel comportement satisfait un certain besoin. En outre elles éveillent la conscience de la nécessité du comportement capable de satisfaire ces besoins et stimulent la raison à former un jugement normatif indiquant comment il faut agir.

${ }^{89}$ Zagadnienie wnioskowania na podstawie zasad prawa przyrodzonego omawiam dokładnie w swej rozprawie: La deduzione delle norme morali generali dalla legge naturale, Roma 1969, 62. 
C'est pourquoi saint Thomas d'Aquin dit:

„Parce que le bien a valeur de fin, et le mal, valeur contraire, il s'ensuit que la raison humaine saisit comme des biens dignes d'être réalisés, toutes les choses auxquelles l'homme se sent porté naturellement; par contre, elle envisage comme des maux à éviter les choses opposées aux précédentes, C'est selon l'ordre même des inclinations naturelles que se prend l'ordre des préceptes de la loi naturelle" (Somme théologique, I-II, q. 94, a. 2).

Il faut bien distinguer la loi naturelles avec ses principes et ses normes. Les principes constituent le point de départ de la conscience morale et d'éthique. On les peut diviser en trois espèces: a nalythiques, basées sur l'évidence de l'implication mutuelle des termes, synthétiques, fondées sur l'observation des faits empiriques et $r$ évélé es par Dieu.

D'après saint Thomas d'Aquin: „Les inclinations naturelles sont les principes de tout ce qui advient par la suite" (Somme Théol. II-II, q. 155 a. 2), dans ce sens qu'elles poussent les hommes à ce qui convient à leur nature, c'est-à-dire, au bien; par exemple à satisfaire les besoins de la vie humaine et à éviter le mal opposé. Ce fait empirique que les inclinations naturelles poussent les hommes à faire le bien et à éviter le mal suggère la formulation du premier principe praxéologique: II faut faire le bien et il faut éviter le mal. Ce principe n'est pas hypothétique, parce que se comporter conformément aux exigences de la raison est précisement l'exigences absolue et catégorique de la nature humaine elle-même. Ce principe est le plus universel, parce que son prédicat: 'il faut faire' ou 'il ne fau't pas faire' embrasse directement ou indirectement tous les autres prédicats pratiques, et son objet: le bien et le mal, sont les motifs les plus généraux de la conduite humaine, puisque tout ce que l'homme fait, il le fait toujours pour quelque bien aimé, pour apaiser quelque besoin, comme l'atteste l'observation du comportement humain. Ce premier principe est analythique, car il suffit comprendre la signification des termes dans lesquels il est exprimé pour saisir sa vérité. Il ne précise pas ce bien à faire on ce mal à éviter. Il nè s'agit certainement pas d'un bien abstrait o d'un mal général, mais d'un comportement dans une situation détérminée par les circonstances observables empiriquement. C'est pourquoi on ne peut pas préciser le bien et le mal moral dans la situation concrète sans connaître empiriquement ces circonstances du sujet, de l'objet, du temps, du lieu, de l'intention, des moyens qu'on trouve à sa disposition etc.

Ce premier principe de la lois naturelle est normatif. Saint Thomas d'Aquin qui l'admet, évite l'objection de $\mathrm{D}$. Hume qu'on ne peut pas déduire une conclusion normative des prémisses qui ne sont pas déontiques. Telle déduction requiert la détermination quel comportement dans telle et telle catégorie des situations constitue un bien ou un mal moral. C'est précisement l'oeuvre de l'éthique laquelle à l'aide des propositions empiriques doit préciser ce qui satisfait les besoins de la vie humaine et convient à la nature humaine conformément aux exigences de la raison bien orientée vers le Bien suprême. Pụisque ,l'ordre de la raison consiste à ordonner convenablement toutes choses à leur fin" (Somme Théol. II-II, q. 153, a. 2), et puisque: „tout ce qui est contre l'ordre de la raison est proprement contre la nature de l'homme considéré en tant que l'homme et ce qui est selon la raison est selon la nature de l'homme en tant que l'homme" (Ib, I-II, q. 71, a. 2), on peut définir le dévoir comme la relation qui rend téléologiquement nécessaire un comportement déterminé en égard à l'exigence de la fin dernière de la vie humaine. La liberté de réaliser ou de ne pas réaliser un act qui n'est pas ni 
necessaire ni contraire à cette fin constitue le droit de la loi naturelle. L'une et l'autre peut être positive ou négative.

Les propositions qui expriment les dévoirs ou les droits de la loi naturelle constituent les normes de cette loi.

Daps les sciences techniques, les normes sont hypothétiques et n'obligent que dans la mesure où l'homme veut la fin dont la réalisation exige des moyens appropriés; tandis que les normes morales obligent souvent les hommes indépendamment de leur volonté: qu'ils veuillent ou non l'obtention de la fin ultime de la vie humaine, ils sont obligés de la vouloir. Pour agir, il est nécessaire de rejoindre la realité concrète, c'est pourquoi, pour déduire les normes morales du principe de la loi naturelle, il faut utiliser des prémisses empiriques, basées sur l'observation des inclinations foncières des hommes.

D'après saint Thomas d'Aquin: „la loi de nature est identique pour tous dans ses premiers principes généraux, elle est identique pour tous dans la plupart des cas et selon la rectitude objective et selon la connaissance qu'on peut en avoir, Toutefois, en quelques cas, elle peut comporter des exceptions dans sa rectitude objective elle même à cause de certains obstacles spéciaux" (Ib, I-II, q. 94, a. 4).

Les prémisses empiriques sont nécessaire pour connaître ces obstacles qu'on recontre dans l'observation des normes de la loi naturelle. Le Docteur Angélique aidmet aussi la possibilité des changements en tel cas particulier, et à titre d'exception, en raison de certaines causes spéciales qui mettent obstacle à l'application de tels précepts" ( $\mathrm{Ib}, \mathrm{a} .5$ ). Le thème de la déduction des normes morales de la loi naturelle à l'aide des prémiesses analythiques et synthétiques ou empiriques est développé dans notre étude: La deduzione delle norme morali generali dalla legge naturale. Istituto degli Studi Ecclesiastici. Roma 1969. Voir aussi: La legge naturale e la perfezione della vita umana, dans: Angelicum V/1 (1978) pp. 58-103. Nous mettons en lumière la nécessité de prémisses empiriques dans les recherches de l'éthique et, notamment, quand celle-ci veut déterminer: le sujet, la fin, les principes, l'objet, l'axiologie et la déontologie de la morale, - dans notre étude: L'Expérience dans l'ethique eudémoniste. Ed. Herder, Roma 1979. Cet étude était écrit après la rédaction de l'article présent, mais avant sa publication. 